\title{
Cannabinoid Ligands and Alcohol Addiction: A Promising Therapeutic Tool or a Humbug?
}

\author{
Patrycja Kleczkowska ${ }^{1}$ Irena Smaga ${ }^{2}$ Małgorzata Filip ${ }^{2,3}$ • \\ Magdalena Bujalska-Zadrozny ${ }^{1}$
}

Received: 17 March 2015/Revised: 4 August 2015/ Accepted: 6 August 2015/Published online: 9 September 2015

(C) The Author(s) 2015. This article is published with open access at Springerlink.com

\begin{abstract}
The vast therapeutic potential of cannabinoids of both synthetic and plant-derived origins currently makes these compounds the focus of a growing interest. Although cannabinoids are still illicit drugs, their possible clinical usefulness, including treatment of acute or neuropathic pain, have been suggested by several studies. In addition, some observations indicate that cannabinoid receptor antagonists may be useful for the treatment of alcohol dependence and addiction, which is a major health concern worldwide. While the synergism between alcohol and cannabinoid agonists (in various forms) creates undesirable side effects when the two are consumed together, the administration of $\mathrm{CB}_{1}$ antagonists leads to a significant reduction in alcohol consumption. Furthermore, cannabinoid antagonists also mitigate alcohol withdrawal symptoms. Herein, we present an overview of studies focusing on the effects of cannabinoid ligands (agonists and antagonists) during acute or chronic consumption of ethanol.
\end{abstract}

Keywords Alcohol · Cannabinoids · Co-administration · Endocannabinoid system

Magdalena Bujalska-Zadrozny

magdalena.bujalska@wum.edu.pl; mbujalska@gmail.com

1 Department of Pharmacodynamics, Centre for Preclinical Research and Technology (CEPT), Medical University of Warsaw, Banacha 1B, 02-097 Warsaw, Poland

2 Department of Toxicology, Faculty of Pharmacy, Jagiellonian University, College of Medicum, Medyczna 9, 30-688 Kraków, Poland

3 Laboratory of Drug Addiction Pharmacology, Department of Pharmacology, Institute of Pharmacology, Polish Academy of Sciences, Smętna 12, 31-343 Kraków, Poland

\author{
Abbreviations \\ AEA Anandamide \\ 2-AG 2-Arachidonoylglycerol \\ eCBs Endocannabinoids \\ FAAH Fatty acid amide hydrolase
}

\section{Introduction}

Cannabis is a term used to describe the psychoactive preparations of the plant Cannabis sativa that is native to mild to tropical regions of Southeast Asia, the Mediterranean, Central America, and South America. Cannabis is also known as marijuana or ganja, however, this refers to cannabis leaves or other crude plant material, and hashish is a resin extracted from the flower clusters and top leaves of the hemp plant. Each of these products contains a number of biologically active substances of which the most important is delta-9-tetrahydrocannabinol $\left(\Delta^{9}\right.$-THC).

Cannabinoids, both those from cannabis extracts and synthetic preparations, are the most frequently used psychoactive drugs around the world. According to World Health Organization estimates, approximately 147 million people (i.e., $2.5-5 \%$ of the world population) use or abuse cannabis compared with $0.3-0.4 \%$ who take cocaine and $0.3-0.5 \%$ who use opioids (WHO 2012). This high prevalence of cannabis abuse results from the fact that cannabis preparations are not always considered harmful drugs, and thus, are typically admitted to official trading. However, cannabis use is not restricted in every country in the world, for example, marijuana and other cannabis preparations are legal in the Netherlands. The Dutch legislation, where cannabis preparations are considered to be of low social and personal risk associated, voted for a 
lenient approach and legalization of cannabis distribution. Additionally, the law in the Czech Republic permits to use cannabis for medical purposes, especially in terminally ill people, including AIDS patients and cancer patients treated for chemotherapy-induced nausea and vomiting (Machado Rocha et al. 2008). Furthermore, cannabis has been found to provide relief from spasticity in multiple sclerosis patients (Sastre-Garriga et al. 2011). A variety of applications of cannabis are also observed in United States of America. Despite prohibition by U.S. federal law, approximately 20 states and the District of Columbia allow the use of marijuana for personal, recreational, or medical use. However, the popularity of cannabinoids is still associated with their use as recreational drugs.

Cannabis products, either smoked or taken orally, induce several behavioral effects that may vary depending on the route of administration, emotional state, dose level, and individual vulnerability to certain effects. While euphoria is the most prominent and dominating effect of cannabis use (Ameri 1999), it can also often lead to tachycardia (Lapoint et al. 2011), antinociception (Chiou et al. 2013), as well as memory and cognitive impairment (Abush and Akirav 2012). Several publications showed that use of cannabinoids, especially marijuana, results in a higher (2-6 times) risk of causing road accidents (Masten and Guenzburger 2014). Furthermore, prolonged exposure to plant-derived, synthetic, or endogenous cannabinoid agonists is associated with the development of pharmacological tolerance (Gonzalez et al. 2005).

In spite of so many undesirable side effects exerted by cannabinoids, it is commonly known that these drugs are also used to intensify pleasure in combination with other psychoactive substances, such as alcohol. In fact, it has been observed that heavy cannabis abusers frequently abuse alcohol as well. Co-consumption of these two substances may be highly inadvisable, especially considering that alcohol might compound the undesirable effects of cannabinoids. The effect of alcohol on our brain and body depends on blood alcohol level and duration of drinking. Interestingly, moderate drinking appears to have health benefits, as it may reduce coronary heart disease risk (Baum-Baicker 1985; Kannel and Ellison 1996; Pinder and Sandler 2004). In addition, alcohol can modify people's emotional state by inducing euphoria, anxiety, or calming effects (Morgan and Badway 2009). However, prolonged regular exposure to alcohol is detrimental to brain cells and may result in serious brain changes associated with brain cell death (Söderpalm et al. 2009). Indeed, like cannabis, chronic alcohol consumption results in detectable impairments in memory (Saults et al. 2007; White 2003) and serious and persistent changes in the brain (e.g., cerebellar degeneration, Marchiafava-Bignami disease, and Wernicke-Korsakoff syndrome) (Ironside et al. 1961; Victor et al. 1971). Additionally, alcohol use can adversely affect the other parts of the body (e.g., liver cirrhosis) (Victor et al. 1959). The development of alcohol tolerance is widely observed in alcohol addicts and can lead to the development of withdrawal symptoms (AWS) when alcohol use is terminated or significantly reduced. Of note, it has been shown that homicide rates rise and fall in accordance with the rise and fall of alcohol consumption (Norstrom 1998; Pridemore 2004).

The above facts suggest that the combination of alcohol and cannabinoids, especially with chronic consumption, may be extremely harmful to the body and mind. However, in contrast to the action of cannabimimetics, several studies have shown that cannabinoid antagonists are efficient in decreasing consumption of alcohol beverages. Thus, combining alcohol consumption with cannabinoid antagonists might provide a new method to treat alcoholism by which the inhibitory action on cannabinoid receptors decreases or blocks alcohol intake by alcohol addicts.

\section{A Brief History of the Endocannabinoid (eCB) System and Discovery of Its Endogenous Ligands}

Several studies concerning pharmacological effects of cannabinoids in the early 1990s led to the discovery of the endogenous cannabinoid system (Devane et al. 1988, 1992). This unique system consists of two cannabinoid receptors, cannabinoid receptor $1\left(\mathrm{CB}_{1}\right)$ and cannabinoid receptor 2 $\left(\mathrm{CB}_{2}\right)$, their endogenous ligands (anandamide, AEA and 2-arachidonoylglycerol, 2-AG) (Fig. 1), and the enzymes that catalyze endocannabinoid $(\mathrm{eCB})$ formation and degradation, such as fatty acid amide hydrolase (FAAH) and monoacylglycerol lipase (Smaga et al. 2014b). The discovery of the first endogenous cannabinoid ligand, which was the ethanol amide of arachidonic acid, took place in 1992. It was named Ananda after a Sanskrit word for pleasure or happiness, and amide due to its chemical structure that distinguishes this endogenous compound from the exogenous agonists (Devane et al. 1992).

In 1995, the second cannabinoid receptor agonist, 2-AG, was discovered (Sugiura et al. 1995). Following this, several other arachidonic acid derivatives were also suggested to be eCBs, including 2-arachidonoylglycerol ether (noladin ether, 2-AGE), $O$-arachidonoyl ethanolamine (virodhamine), $\mathrm{N}$-arachidonoyl dopamine (NADA), $\mathrm{N}$-arachidonoyl glycine (NAGly), and cis-9,10-octadecanoamide (ODA) (Huang et al. 2001; Leggett et al. 2004; Porter et al. 2002). Unlike other neurotransmitters, AEA and 2-AG are not stored in secretory vesicles but are synthesized "on demand" in the postsynaptic neurons (Ahn et al. 2008).

Most of the actions of eCBs are mediated through the G-protein-coupled receptors, $\mathrm{CB}_{1}$ and $\mathrm{CB}_{2}$, which are 
Fig. 1 Chemical structures of putative endogenous cannabinoids<smiles>CCCCCC=CCC=CCC=CCC=CCCCC(=O)NCCO</smiles>

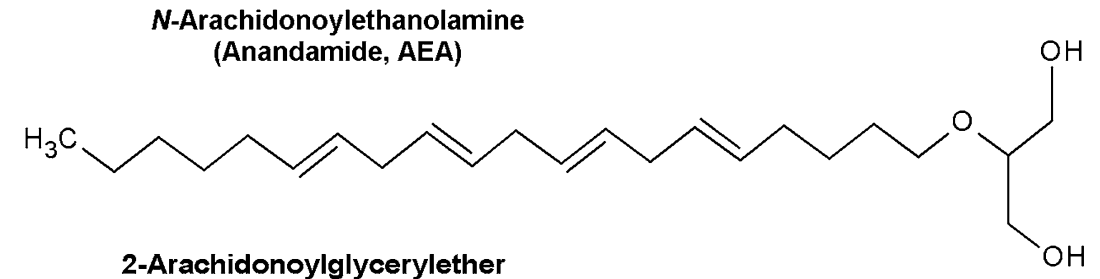

\section{(Noladin ether, 2-AGE)}

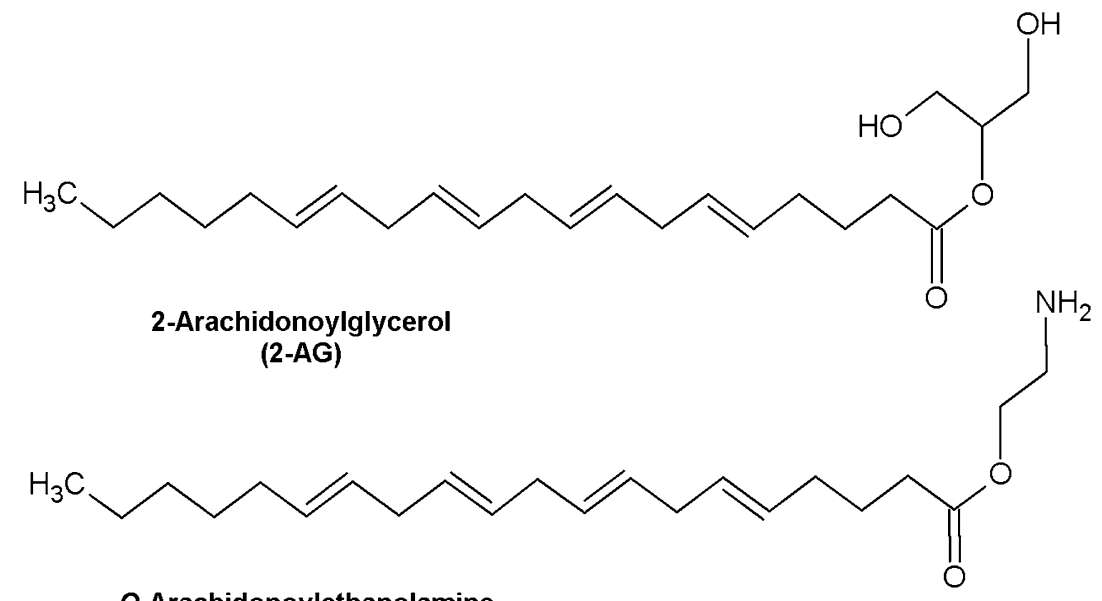

O-Arachidonoylethanolamine (Virodhamine)<smiles>CCCCCCCC/C=C/CCCCCCCC(=O)NCCO</smiles>

$N$-Oleoylethanolamine (OEA)

characterized by distinct distributions throughout the body. $\mathrm{CB}_{1}$ receptor expression is diffuse and widespread mainly in the periaqueductal gray matter of the brain (Wilson-Poe et al. 2012). Markedly high expression also exists in the substantia nigra, limbic areas (hippocampus, amygdala, cingulate cortex), and the cerebral cortex, especially the frontal cortical areas (Herkenham et al. 1991). Because of their wide distribution on neurons, $\mathrm{CB}_{1}$ receptors may play an important role in regulating several physiological processes. For example, $\mathrm{CB}_{1}$ receptors are present on axonal terminals, thus having contacts with the GABAergic neurons of the nucleus accumbens (NAc). Consequently, this is 
found to result in the inhibition of synaptic glutamate release independently of cAMP levels (Rubbie et al. 2001). The presence of CB1 receptors in the dorsal root ganglia is also well known (Morisset et al. 2001), which may contribute to the analgesic effectiveness of cannabinoid agents. Furthermore, co-localization experiments show that CB1 receptors may be present in somatostatin-positive neurons of the lateral septum (Hohmann and Herkenham 2000).

In contrast to $\mathrm{CB}_{1}$ receptors, $\mathrm{CB}_{2}$ receptors are predominately found in cells of the immune system; however, they are present on both microglia and on neurons in the nervous system (Onaivi et al. 2006). Importantly, although several papers demonstrated $\mathrm{CB}_{2}$ receptor expression in almost all of the neurons of a healthy mouse brain, these reports did not include the required negative controls for assessing immunostaining specificity (Gong et al. 2006; Onaivi et al. 2006). Other than these two well-characterized cannabinoid receptors, the existence of a third putative cannabinoid receptor has also been postulated (Ryberg et al. 2007). This orphan G-protein-coupled receptor, known as GPR55, is known to bind to a range of endogenous, plantderived and synthetic cannabinoid ligands. Despite some similarities with $\mathrm{CB}_{1}$ and $\mathrm{CB}_{2}$ receptors, the function of this third cannabinoid receptor seems to be far more complex.

\section{Other Cannabinoid Receptor Ligands (Natural and Synthetic)}

Naturally occurring cannabinoids derived from the cannabis plant constitute a group of chemically related 21-carbon alkaloids, of which $\Delta^{9}$-THC is the principal active ingredient, belonging to the herbal cannabinoid family. The activities of $\Delta^{9}$-THC and a non-psychoactive cannabinoid of marijuana, cannabidiol (CBD), are well characterized. These compounds may be useful for the treatment of many diseases; CBD has demonstrated neuroprotective and neurogenic effects whereas $\Delta^{9}$-THC is widely used as an antinociceptive drug (Consroe et al. 1986; Formukong et al. 1988; Müller-Vahl et al. 1999). Information on the pharmacology and toxicology of the other cannabinoids (Fig. 2) is available, especially regarding their possible roles in treating several diseases (Borrelli et al. 2013) and enhancement of $\Delta^{9}$-THC-induced effects (Karniol et al. 1975).

To date, many cannabinoid receptor agonists and antagonists have been synthesized and intensively investigated. Most of them are structurally based on $\Delta^{9}$-THC (especially agonists) or mimic its effects. The number of such synthetic agonists has dramatically increased due to the continuously evolving market that is full of synthetic cannabinoid products containing $\Delta^{9}$-THC-like ingredients, such as "Spice," "K2," "Clockwork Orange," "Black Mamba" (Zawilska and Wojcieszak 2014). The European Monitoring Centre for Drugs and Drug Addiction
(EMCDDA) reported that by March 31st, 2014, almost 110 new synthetic cannabinoids have been detected in "Spice" products available in Europe (Zawilska and Wojcieszak 2014). However, according to the instructions found on the packaging of these products, they are not meant to be consumed by humans, and many users reported smoking or taking such products orally as "speed."

Due to the continuously increasing list of synthetic cannabinoid compounds and a variety of chemical structures they contain, Howlett et al. (2002) suggested a classification of the synthetic cannabinoids based on their chemical structure. Namely, they described classical, nonclassical (HU-308), and hybrid cannabinoid (AM919, AM4030) groups. Additionally, this classification includes aminoalkylindoles (AAIs), which can be further divided into naphthoylindoles (e.g., JWH-018, JWH-073, JWH398, JWH-015, JWH-210, JWH-081, JWH-200, WIN55,212; AM2201), phenylacetylindoles (e.g., JWH-250, JWH-251), naphthylmethylindoles (JWH-185, JWH-199), and benzoylindoles (e.g., pravadoline, AM-694, RSC4);

- eicosanoids (eCBs such as AEA, and their synthetic analogs, e.g., methanandamide);

- and others, including diarylpyrazoles (selective $\mathrm{CB}_{1}$ antagonist Rimonabant $^{\circledR}$ ), naphtoylpyrroles (JWH307), naphthylmethylindenes, and derivatives of naphthalene-1-yl-(4-pentyloxynaphthalen-1-yl)methanone (CRA-13).

The pharmacological properties of some of the presented cannabinoid ligands have been well examined, and many of these compounds appeared to be selective $\mathrm{CB}_{1}$ receptor agonists or antagonists. Moreover, some, such as nabilone, have been used for medical purposes, which is currently used for treatment of nausea and vomiting caused by cytotoxic chemotherapy that is unresponsive to conventional antiemetics. More detailed information about the nature of several existing cannabinoid receptor agonists and antagonists is summarized in the next chapters.

\section{Agonists}

The discovery of $\Delta^{9}$-THC and the knowledge of its properties and availability opened a new path to developing highly selective and potent cannabinoid receptor agonists. The intensive synthesis of new compounds, the structures of which are based on the active principal of cannabis, resulted in a great number of active cannabimimetics. Interestingly, several of these novel ligands have a much greater potency than $\Delta^{9}$-THC, suggesting that other compounds that are present in herbal marijuana (or other herbal extracts) may influence $\Delta^{9}$-THC activity.

Dronabinol is a synthetic $\Delta^{9}$-THC formulation and one of the first cannabinoid receptor agonists that displays 
Fig. 2 Representative plantderived cannabinoids

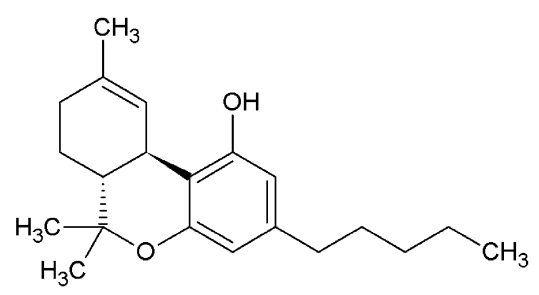

(-)-delta9-THC

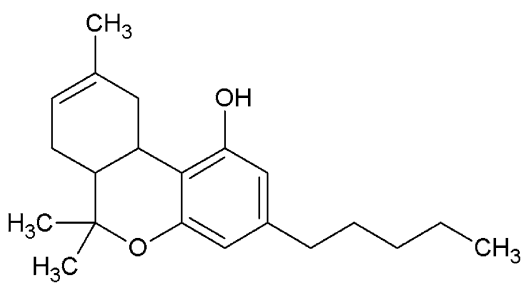

delta8-THC<smiles>C=C(C)[C@@H]1CCC(C)=CC1c1c(O)cc(CCCCC)cc1O</smiles>

(-)-Cannabidiol<smiles>CCCCCC1=CC(O)=C2c3cc(C)ccc3C(C)(C)OC2C1</smiles>

Cannabinol affinity for $\mathrm{CB}_{1}$ and $\mathrm{CB}_{2}$ receptors. However, it behaves only as a weak agonist for $\mathrm{CB}_{2}$ receptors and is used as an appetite stimulant in HIV patients with anorexia. As shown by Beal et al. (1995), administration of capsules containing $2.5 \mathrm{mg}$ of dronabinol twice a day caused an average weight gain of $0.1 \mathrm{~kg}$ versus an average loss of $0.4 \mathrm{~kg}$ in the placebo group (Beal et al. 1995). Additionally, several papers have demonstrated that this novel compound is an efficient analgesic and is a useful therapy for chronic noncancer pain patients who take stable doses of opioids (Narang et al. 2008). Finally, agonist substitution has been an effective strategy for promoting abstinence from many substances of abuse (e.g., nicotine, opioids), and dronabinol has been proposed to serve as a replacement drug in cannabis addiction (Vandrey et al. 2013), especially in cases where withdrawal can be a significant barrier to cessation. Like nabilone it is used as an antiemetic drug in vomiting induced by cytotoxic agents (Tramèr et al. 2001).

Nabilone $\left(\right.$ Cesamet $^{\circledR}$ ) is another synthetic cannabinoid characterized by an affinity of $2.2 \mathrm{nM}$ for human $\mathrm{CB}_{1}$ and $1.8 \mathrm{nM}$ for $\mathrm{CB}_{2}$ receptors. This compound is used to treat nausea associated with cancer chemotherapy (Maida et al. 2008). Nabilone also appears to be a promising candidate agonist for substitutive medication for cannabinoid agonist replacement treatment of cannabis use disorders (Lile et al. 2010). In addition, consumption of nabilone resulted in drug-appropriate responses in subjects who learned to discriminate from $\Delta^{9}$-THC (Lile et al. 2010). Several other studies have indicated that nabilone is a potent and effective drug for the treatment of various disorders, mainly related to pain. For example, in a randomized, double-blind placebo-controlled trial, nabilone suppressed pain and increased functional capacity in fibromyalgia patients (Skrabek et al. 2008).
Similar analgesic properties are also observed with Sativex, a cannabinoid extract oral spray containing both $\Delta^{9}$-THC and CBD, which is commercially available for neuropathic pain and spasticity in 25 countries primarily in Europe (Myers and Shetty 2008; Nurmikko et al. 2007; Palmer 2014). A selective $\mathrm{CB}_{2}$ cannabinoid receptor agonist, O-3223, is an additional compound that can reduce pain and inflammation without apparent cannabinoid-like behavioral effects (Kinsey et al. 2011).

Considering the pharmacological profile of other cannabinoid ligands, WIN 55,212-2 appears to be very interesting. Aside from its antinociceptive activity, this nanomolar affinity cannabinoid receptor agonist $\left(\mathrm{K}_{\mathrm{i}}\right.$ values of 62.3 and $3.3 \mathrm{nM}$ at the human recombinant $\mathrm{CB}_{1}$ and $\mathrm{CB}_{2}$ receptors, respectively) has also been reported to reduce endothelial cell (EC) inflammatory responses induced by bacterial lipopeptide and $\mathrm{TNF} \alpha$ as well as to promote neural repair processes after neonatal hypoxiaischemia (Fernandez-Lopez et al. 2010; Wilhelmsen et al. 2014). Importantly, such a neuroprotective activity was also observed in both global and focal cerebral ischemia and was blocked by a selective $\mathrm{CB}_{1}$ receptor antagonist, SR141716A (Nagayama et al. 1999; Shen et al. 1996). Unfortunately, this antagonist also caused several side effects and enhanced locomotor responses when combined with other psychoactive drugs (e.g., heroin, amphetamine) (Lamarque et al. 2001). On the contrary, CP-55,940, another cannabimimetic, did not enhance sensitivity to the behavioral effects of cocaine. Moreover, its co-administration with cocaine reduced the locomotor hyperactivity produced by the psycho-stimulant (Arnold et al. 1998). Despite the fact that this compound is found to be almost 45 times more potent than $\Delta^{9}-\mathrm{THC}$ and is considered to be a full agonist at both $\mathrm{CB}_{1}\left(K_{i}=0.58 \mathrm{nM}\right)$ and $\mathrm{CB}_{2}$ 
$\left(K_{i}=0.68 \mathrm{nM}\right)$ receptors, it has not yet been approved for human medical use, as the adverse effects and long-term damage and addiction potential of CP-55,940 are not yet known.

The list of potent agonists at either $\mathrm{CB}_{1}$ or $\mathrm{CB}_{2}$ receptors is relatively long. Despite their reported efficacy in many biological conditions, most cannabinoid agonists are not currently used in clinic and are instead used as tools for cannabinoid research.

\section{Antagonists}

SR141716A, also known as rimonabant, is the most potent and orally active antagonist of the $\mathrm{CB}_{1}$ receptor. This compound, discovered by the laboratory of Rinaldi-Carmona, displays nanomolar affinity for $\mathrm{CB}_{1}\left(K_{i}=1.98 \mathrm{nM}\right)$ and micromolar for human $\mathrm{CB}_{2}$ receptors expressed in $\mathrm{CHO}$ cells (Rinaldi-Carmona et al. 1994). Intensive studies have suggested its anorectic activity (Freedland et al. 2000). Indeed, several papers demonstrated that intake of different diets seemed to be sensitive to dose-dependent, antagonistinduced cannabinoid receptor blockade, which does not significantly alter other normal behaviors (Freedland et al. 2000; Tucci et al. 2006). Accordingly, other well-known antagonists are able to exert similar effects as rimonabant, including AM251 [N-(piperidin-1-yl)-5-(4-iodophenyl)-1(2,4-dichlorophenyl)-4-methyl-1H-pyrazole-3-carboxamide], which is a selective and potent $\mathrm{CB}_{1}$ receptor antagonist with well-characterized anorectic effects in freely fed animals (Hildebrandt et al. 2003); and novel antagonists LH21 (Pavon et al. 2006), and URB477 (LoVerme et al. 2009).

Due to the anti-obesity activity of $\mathrm{CB}_{1}$ receptor antagonists, they may be considered to be promising tools to treat obesity disorders. However, application of these compounds leads to several serious adverse effects. For instance, the study by Moreira and Crippa (2009) showed that $\mathrm{CB}_{1}$ receptor blockade impaired fear elimination (Moreira and Wotjak 2010). Additionally, an increased incidence of depression and aggression has been reported, including an increase in suicidal thoughts (Christensen et al. 2007).

On the contrary, the first $\mathrm{CB}_{2}$ receptor antagonist SR144528, having $K_{i}$ values of $0.6 \mathrm{nM}$ at $\mathrm{CB}_{2}$ and $400 \mathrm{nM}$ at $\mathrm{CB}_{1}$ (Rinaldi-Carmona et al. 1998), as well as other recently discovered $\mathrm{CB}_{2}$ receptor antagonists (e.g., JTE907) can markedly reduce ear swelling in chronic contact dermatitis induced either by repeated challenge with oxazolone (Oka et al. 2006) or by repeated exposure to dinitrofluorobenzene in mice (Ueda et al. 2005). However, in comparison with some of the $\mathrm{CB}_{1}$ receptor agonists and antagonists, none of the existing $\mathrm{CB}_{2}$ receptor antagonists are listed as controlled substances worldwide.

Of importance, because many $\mathrm{CB}_{1}$ antagonists are, in fact, partial or inverse agonists (e.g., AM281, AM251,
SR141716A), they may produce significantly different effects via different mechanisms of action. These effects may also depend on the state of endocannabinoid signaling pathway. Therefore, further studies are warranted to establish the complete pharmacological profile of such compounds.

\section{The Endocannabinoid System and Alcohol}

The eCB system is involved in the modulation of emotional responses, memory, learning, and reward systems. Importantly, there are many indications that this system is involved in alcohol-induced impairments, namely $\mathrm{CB}_{1}$ receptor function is implicated in functional modulation of the mesocorticolimbic dopaminergic pathway and motivation for drug seeking (Bystrowska et al. 2014; Parolaro et al. 2007; Smaga et al. 2014a, b). Several biochemical studies revealed changes within the components of the eCB system after acute and chronic alcohol intake (Basavarajappa and Hungund Basavarajappa and Hungund 1999a, 1999b; Basavarajappa et al. Basavarajappa et al. 2000a, 2000b; Gonzáles et al. Gonzalez et al. 2002a, b and Gonzalez et al. 2002c). Pharmacological studies using CB ligands found alterations in alcohol-related behavior while genetic studies demonstrated changes in different rodent strains (Erdozain and Callado 2011).

\section{The effects of Ethanol Exposure on the eCB System}

\section{Preclinical Studies}

Preclinical experiments demonstrated that acute exposure to alcohol reduced tissue concentrations of AEA in several rat brain structures including limbic and subcortical areas (Ferrer et al. 2007; Rubio et al. 2007) and the level of 2-AG in the prefrontal cortex (Rubio et al. 2007) (see Table 1). Interestingly, the reduction in eCB levels following acute alcohol administration was correlated with a decrease in glutamate release, which can modulate the release of other neurotransmitters (Ferrer et al. 2007). In contrast with tissue levels, eCBs levels increased in dialysates and in hippocampal cell cultures, (Basavarajappa et al. 2008) whereas 2-AG levels increased in the nucleus accumbens (Caille et al. 2007) after acute alcohol treatment. The increased 2-AG levels in limbic structures may be involved in the elevated alcohol consumption and preference in methamphetamine-lesioned mice that serve as a model of enhanced alcohol intake (Gutierrez-Lopez et al. 2010). Fatty acid amide hydrolase (FAAH) activity was reduced in the hypothalamus, prefrontal cortex (Rubio et al. 2009), and hippocampus (Ferrer et al. 2007) after acute administration of alcohol. However, the levels of FAAH protein 


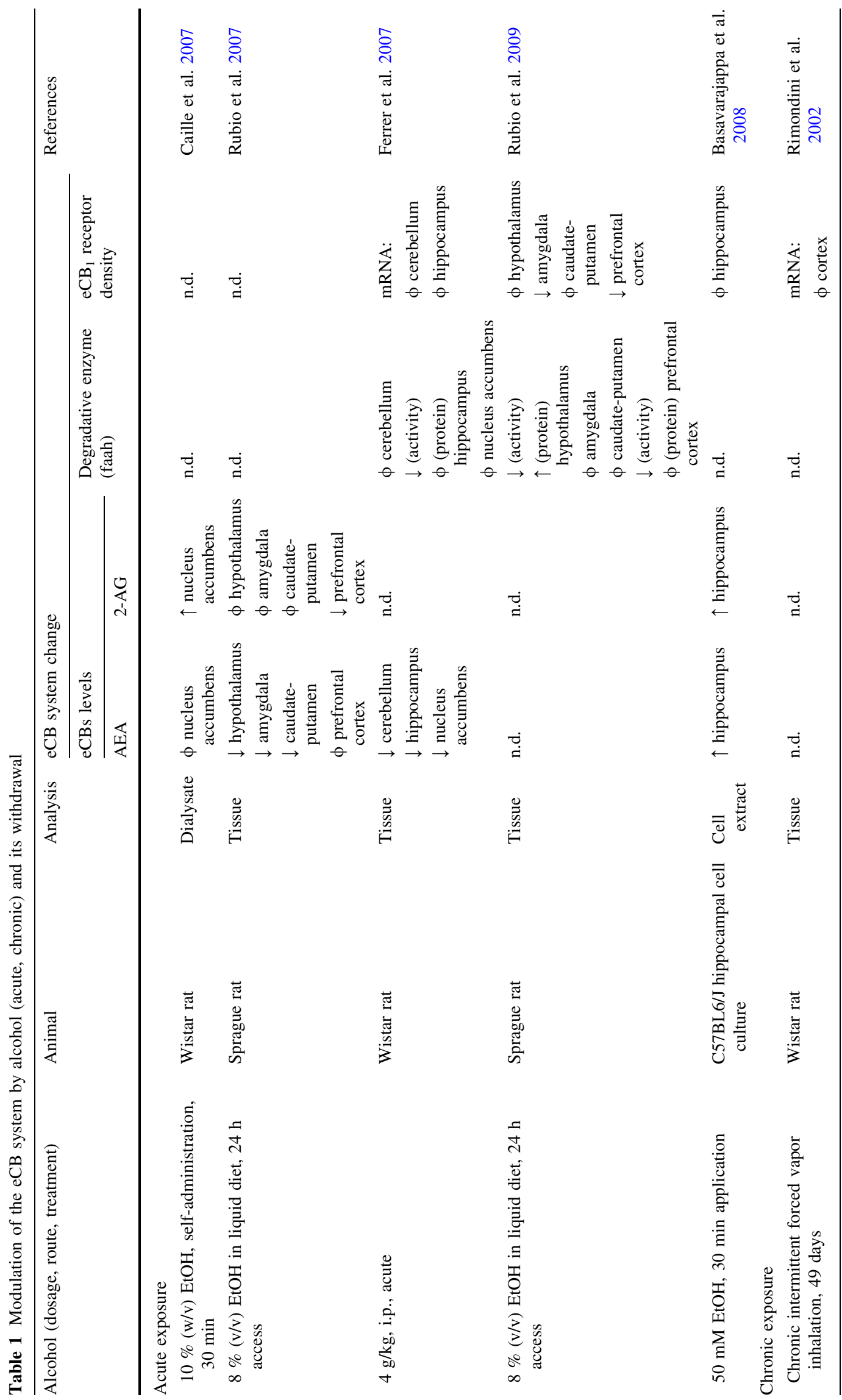




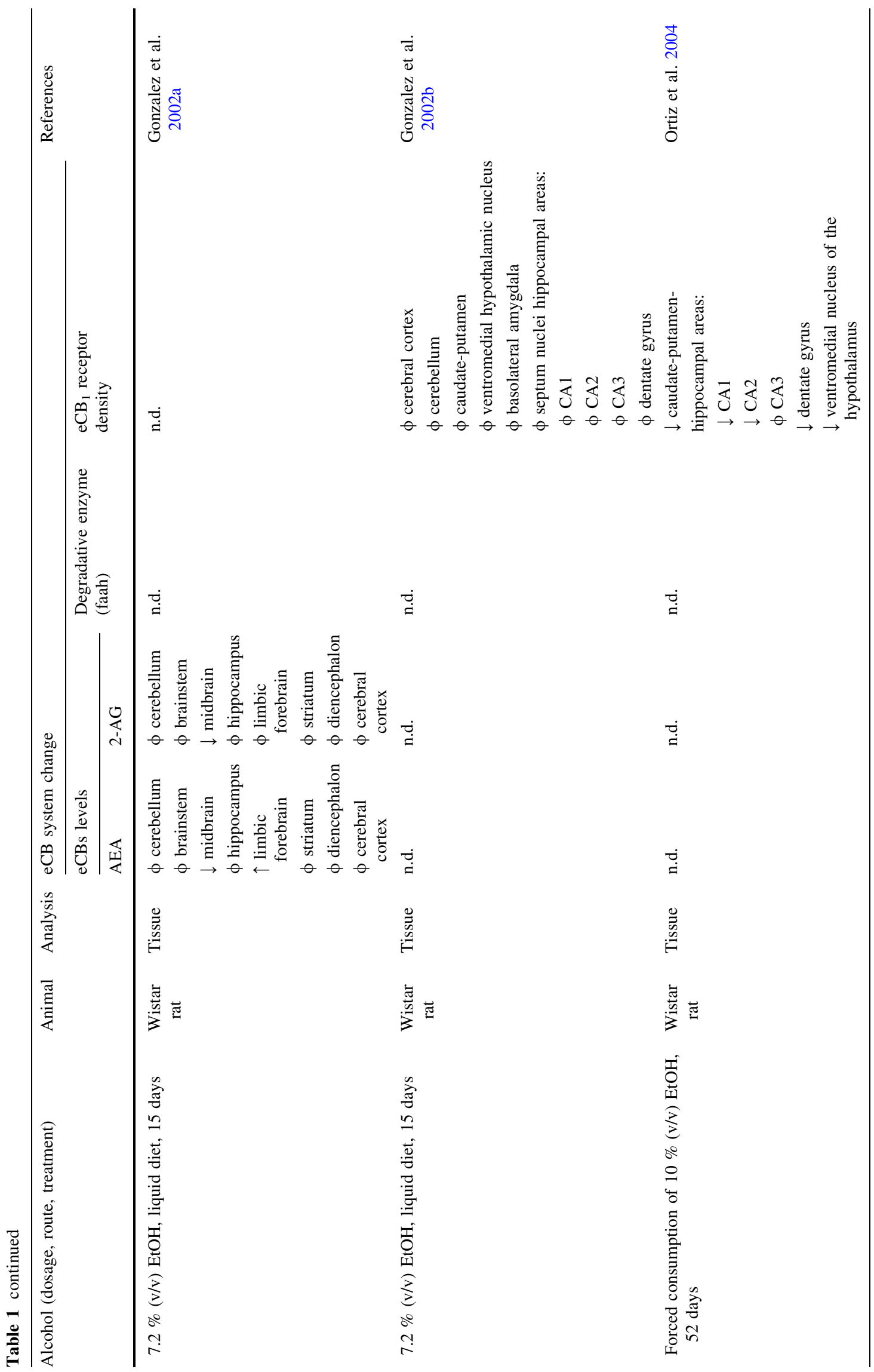




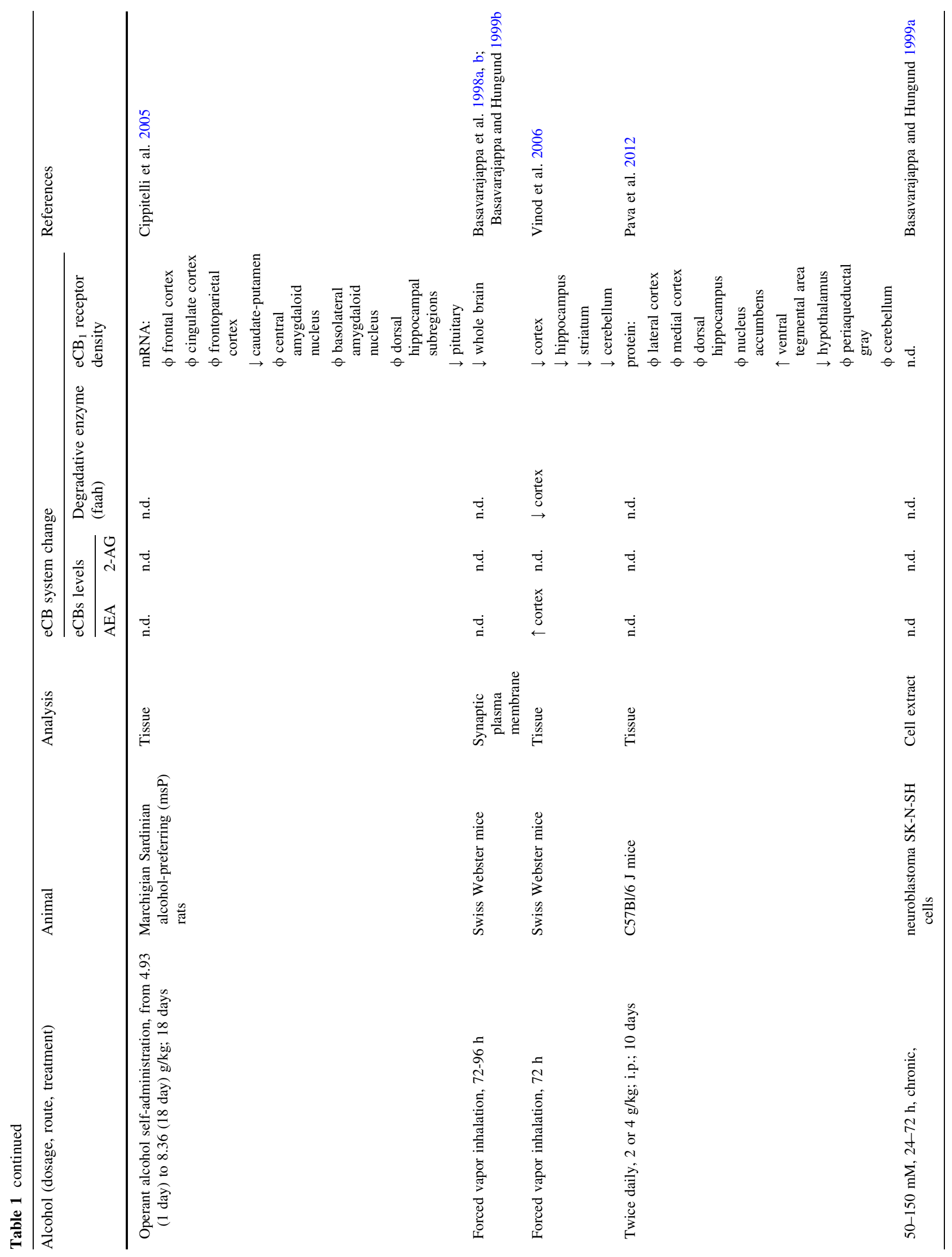




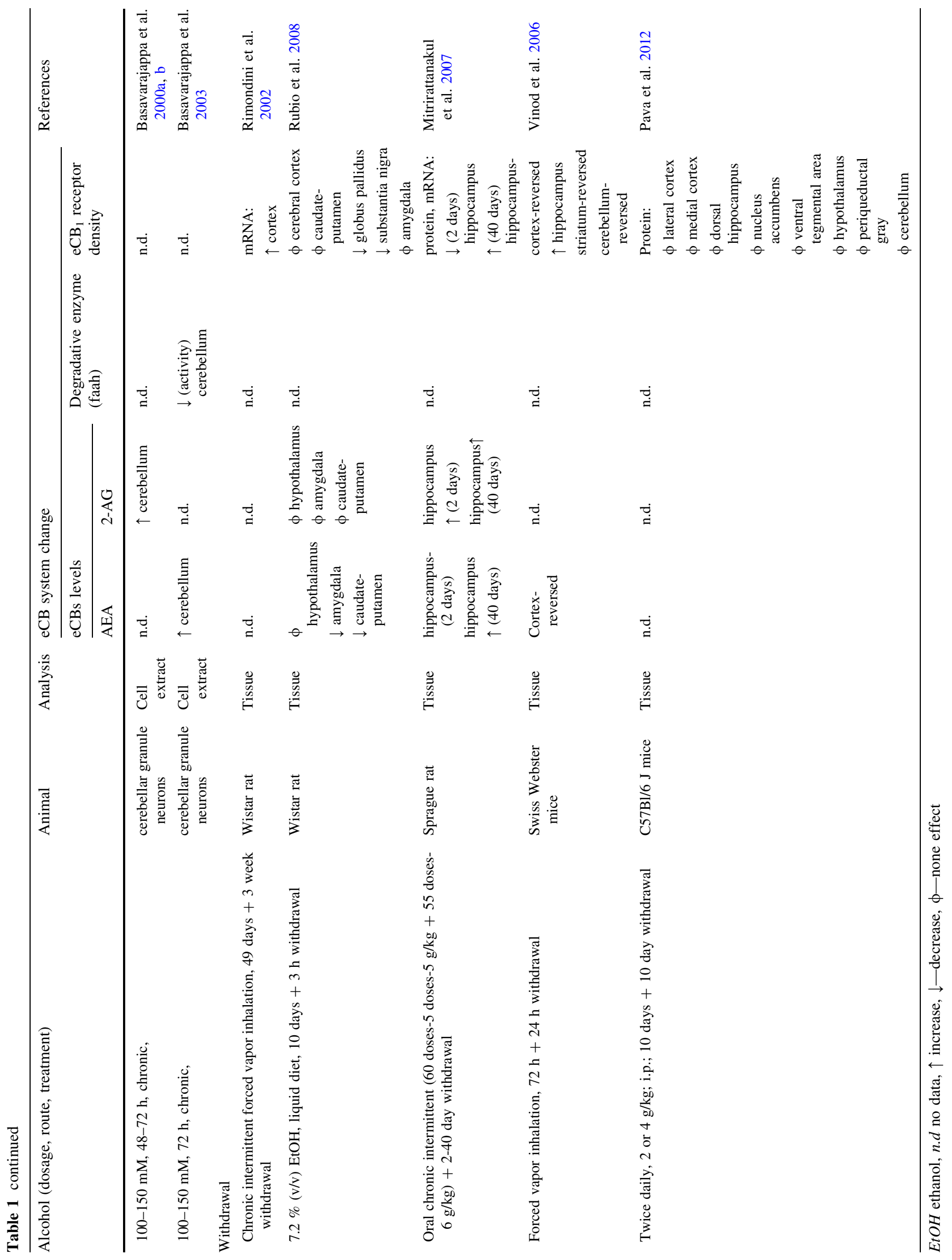


were increased, probably as a compensatory response to the primary effect of alcohol on its enzyme function (Rubio et al. 2009). In line with the reduced FAAH activity and enhanced AEA levels, $\mathrm{CB}_{1}$ receptor density decreased in the prefrontal cortex and amygdala (Rubio et al. 2009) (Table 1).

Chronic alcohol intoxication evoked a reduction in $\mathrm{eCB}$ levels in the midbrain and an increase in AEA levels in the limbic forebrain in rats (Gonzalez et al. 2002a). The increased AEA levels in the limbic area, which is a key region for drug reinforcement processes, may be involved in the eCB-induced elevation of synaptic transmission, which leads to the addictive properties of alcohol. At the same time, reduced eCB levels in the midbrain may be a compensatory response induced by the activation of the negative feedback regulatory loop from the limbic forebrain to the ventral tegmental area (Gonzalez et al. 2002a). In another study, AEA levels increased in the cortex in mice simultaneously with decreasing cortical FAAH activity (Vinod et al. 2006). The rise in AEA levels may be associated with the activation of phospholipase $\mathrm{A}_{2}\left(\mathrm{PLA}_{2}\right)$, which is a crucial enzyme for eCB formation as shown in an animal model of chronic alcohol consumption (Basavarajappa et al. 1998b). It was also documented that chronic alcohol exposure might increase the levels of eCBs by inhibiting the AEA transporter in neurons exposed to chronic alcohol, and chronic alcohol additionally prevented AEA inactivation (Basavarajappa et al. 2003).

It was speculated that a rise in the levels of eCBs led to down-regulation of the $\mathrm{CB}_{1}$ receptors. In fact, chronic exposure to alcohol evoked a reduction in $\mathrm{CB}_{1}$ receptor density in mice (Basavarajappa et al. 1998a; Basavarajappa and Hungund 1999b; Vinod et al. 2006) and in rats (Ortiz et al. 2004). However, this phenomenon was not observed in earlier research in the rat brain (Gonzalez et al. 2002b; Rimondini et al. 2002) likely due to differences between the two experimental designs (alcohol intake, experimental time, etc.).

Moreover, chronic alcohol consumption may inhibit some processes related to gene expression. In Marchigian Sardinian alcohol-preferring (msP) rats, $\mathrm{CB}_{1}$ receptor mRNA expression was increased and chronic alcohol consumption reduced $\mathrm{CB}_{1}$ receptor mRNA levels in the caudate-putamen and pituitary, the brain areas relevant to the processing of reward and reward-associated behaviors (Cippitelli et al. 2005). In C57Bl/6J mice, chronic alcohol consumption induced a decrease in $\mathrm{CB}_{1}$ receptor density in the hypothalamus and an increase in $\mathrm{CB}_{1}$ density in the ventral tegmental area (Pava et al. 2012). Ten-day treatment of mice with alcohol also resulted in a reduction in the hypolocomotive, antinociceptive, and hypothermic effects of an acute dose of the $\mathrm{CB}_{1}$ agonist WIN 55,212-2, while a 10-day withdrawal period reversed this effect (Pava et al. 2012). Together, these data suggest that $\mathrm{CB}_{1}$ receptors play an important role in the neurochemical processes related to alcohol consumption.

Additionally, Agudelo et al. (2013) was the first to provide evidence of up-regulation of $\mathrm{CB}_{2}$ and GPR55 (the third putative cannabinoid receptor) in monocyte-derived dendritic cells from alcohol abusers. Ethanol-treated cells demonstrated higher levels of $\mathrm{CB}_{2}$ and GPR55 mRNA. Furthermore, it was observed that alcohol significantly modulated dendritic cells to produce higher levels of the pro-inflammatory cytokine IL-1 $\beta$ (Agudelo et al. 2013). Thus, these receptors may play an immunoprotective role during alcohol-induced immune dysfunction. It has also been reported that $\mathrm{CB}_{2}$ receptor agonists have the ability to positively regulate Kupffer cells, which result in liver injury when activated by endotoxins in alcohol drinking individuals, and $\mathrm{CB}_{2}$ receptors play a role in alcohol-induced inflammation (Louvet et al. 2011).

In vitro studies showed increased AEA (Basavarajappa et al. 2003) and 2-AG (Basavarajappa et al. Basavarajappa et al. 2000a, b) levels in cerebellar granule neurons with reduced FAAH activity (Basavarajappa et al. 2003) and increased AEA levels in neuroblastoma SK-N-SH cells after chronic alcohol exposure (Basavarajappa and Hungund 1999a) (Table 1). A rise in these lipid mediators may serve as a neuronal compensatory adaptation in the chronic presence of alcohol, and it should be noted that this increase was not dependent on alcohol-induced AEA transporter inhibition.

Alcohol abstinence also provoked changes within the eCB system. The increase in AEA levels was reversed in the mouse cortex (Vinod et al. 2006) and in the rat amygdala and caudate-putamen (Rubio et al. 2008). The reduced level of AEA was accompanied by a low glutamate concentration in the amygdala, and thus, it appears to be related to reduced NAPE-phospholipase D activity that depends on glutamate-mediated calcium influx (Hansen et al. 2000; Rubio et al. 2008). Another study indicated that eCB levels increased in the hippocampus after 40 days of abstinence. Specifically, increased 2-AG levels were rapidly observed only after 2 days of abstinence. Interestingly, $\mathrm{CB}_{1}$ receptor levels were reduced after 2 days and increased after 40 days of alcohol abstinence (Mitrirattanakul et al. 2007). The increased eCB production was the result of chronic increases in hippocampal excitability on the terminals of GABAergic interneurons and in consequence may have reduced long-term increases in $\mathrm{CB}_{1}$ activation on GABA release (Mitrirattanakul et al. 2007). An increase in $\mathrm{CB}_{1}$ receptors was also observed in the cortex (Rimondini et al. 2002) and hippocampus (Vinod et al. 2006), while alcohol abstinence reversed the reduced levels of $\mathrm{CB}_{1}$ in the cortex, striatum, and cerebellum in rats (Vinod et al. 2006). On the other hand, a reduction of $\mathrm{CB}_{1}$ receptors was found in the globus pallidus and substantia 
nigra (Rubio et al. 2008). In C57Bl/6J mice, 10-day abstinence evoked normalization in $\mathrm{CB}_{1}$ protein expression in the hypothalamus and ventral tegmental area (Pava et al. 2012). Apart from the present review, there is another excellent paper showing in details the preclinical interactions between alcohol and the brain eCB system (Pava and Woodward, 2012). Moreover, the effects of drugs of abuse (particularly cocaine) on the eCB system are described in the recent review paper of Vlachou and Panagis (2014). Based on the above preclinical knowledge of the role of the eCB system in processes related especially to alcohol consumption further studies on alcohol use disorder in which the eCB system plays a crucial role are urgently required.

\section{Clinical Studies}

In postmortem studies, elevated levels of eCBs were observed in the dorsolateral prefrontal cortex of alcoholic suicide victims and were suggested to inhibit GABAergic signaling and provoke impulsivity (Vinod et al. 2005). The increased eCBs levels may also play a role in reinforcing the effects of alcohol or may act more directly as a neuroprotective adaptation to chronic alcohol abuse. Although $\mathrm{CB}_{1}$ receptors were increased in the dorsolateral prefrontal cortex (Vinod et al. 2005) and in the ventral striatum (Vinod et al. 2010) of alcoholic suicide victims, the latter changes were not associated with alcohol dependence, as a down-regulation of $\mathrm{CB}_{1}$ receptors was noted in alcohol-dependent nonsuicide victims (Smaga et al. 2014b; Vinod et al. 2010). An increase in FAAH activity was identified in the ventral striatum of alcohol-dependent suicide victims compared with alcohol-dependent non-suicide victims (Vinod et al. 2010). Another study showed a decrease in AEA levels in the nucleus accumbens and frontal cortex of Cloninger type 1 alcoholics with a reduced dopaminergic transmission in the accumbal reward system (Lehtonen et al. 2010).

\section{The effects of eCB system modulation on alcohol consumption}

\section{Preclinical Studies}

A large body of data suggested that a genetic predisposition to alcohol abuse depends on a disturbance of the eCB system. In fact, $\mathrm{CB}_{1}$ receptor knockout mice generated on a $\mathrm{CD}_{1}$ genetic background (outbred $\mathrm{CD}_{1}$ mouse strain) demonstrated a reduction in alcohol-induced conditioned place preference (CPP) (Houchi et al. 2005; Thanos et al. 2005) and a decrease in consumption of alcoholic solution in the two-bottle choice test (Naassila et al. 2004). The same decreased voluntary intake of alcohol was demonstrated in
C57BL/6J mice with genetic deletion of the $\mathrm{CB}_{1}$ receptor gene (Lallemand and de Witte 2005; Poncelet et al. 2003; Vinod et al. 2008b; Wang et al. 2003). Additionally, genetic deletion of FAAH in C57BL/6J mice provoked an increase in voluntary alcohol intake in the two-bottle choice protocol (Basavarajappa et al. 2006; Blednov et al. 2007; Vinod et al. 2008a). These studies confirmed the involvement of $\mathrm{CB}_{1}$ receptors in alcohol abuse, and pharmacological blockade of these receptors seems to be a rational approach to the treatment of alcohol addiction.

Accumulated experimental data on cannabis and alcohol interactions have suggested that cannabinoids may act either as substitutes in alcohol withdrawal by counteracting withdrawal symptoms such as tremor and nausea, or as therapeutic agents to help in alcohol cessation. Indeed, it has been demonstrated that stimulation of eCB signaling using the cannabinoid receptors agonists CP55,940 (Colombo et al. 2002; Gallate et al. 1999; Vinod et al. 2008b) and WIN 55,212-2 (Alen et al. 2009; Colombo et al. 2002; Linsenbardt and Boehm 2009; Lopez-Moreno et al. 2004), the selective AEA reuptake inhibitor AM404 (Cippitelli et al. 2007) or the FAAH inhibitor URB597 (Blednov et al. 2007; Cippitelli et al. 2008; Hansson et al. 2007; Vinod et al. 2008a) influences alcohol intake. It was reported that activation of the eCB system increased alcohol consumption. Specifically, acute administration of non-selective $\mathrm{CB}_{1} / \mathrm{CB}_{2}$ receptor agonists CP55,940 (Colombo et al. 2002; Gallate et al. 1999; Vinod et al. 2008b) and WIN 55,212-2 (Alen et al. 2009; Colombo et al. 2002; Linsenbardt and Boehm 2009; Lopez-Moreno et al. 2004) decreased the development of alcohol CPP (Lopez-Moreno et al. 2004). The development and enhancement of alcohol preference was also observed after chronic treatment with the $\mathrm{CB}_{2}$ agonist JWH 015 in stressed mice, but not in controls (Onaivi et al. 2008). Regarding WIN 55,212-2, it should be noted that higher doses of this drug injected systemically or into the ventral tegmental area provoked reduction of alcohol intake in mice (Linsenbardt and Boehm 2009). Increased AEA levels induced by inhibition of FAAH by URB597 evoked either a rise in alcohol consumption (Blednov et al. 2007; Hansson et al. 2007; Vinod et al. 2008a) or no effect in Marchigian Sardinian alcohol-preferring (msP) rats, and this treatment additionally had potent anxiolytic-like properties (Cippitelli et al. 2008). Interestingly, the increased levels of AEA after acute administration of the selective AEA reuptake inhibitor AM404 reduced the number of active lever responses in rats during alcohol self-administration. Additionally, AM404 did not affect the relapse induced by contextual cues associated with alcohol (Cippitelli et al. 2007). It should be noted that these effects were not mediated via $\mathrm{CB}_{1}, \mathrm{CB}_{2}$, or TRPV1 receptors but via other targets in the $\mathrm{eCB}$ system. On the whole, facilitation of brain $\mathrm{eCB}$ signaling seemingly contributes to alcohol consumption (Table 2). 


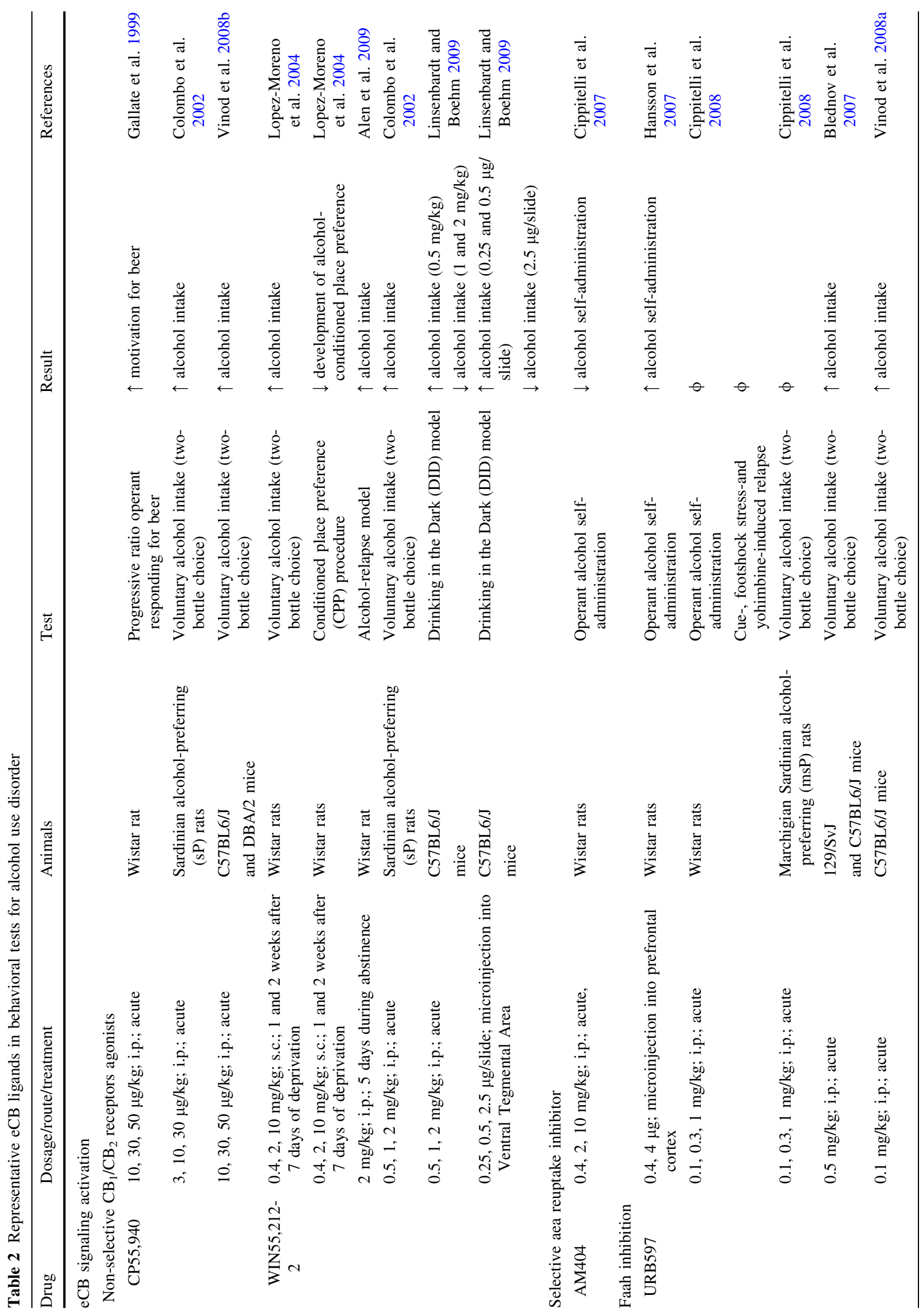




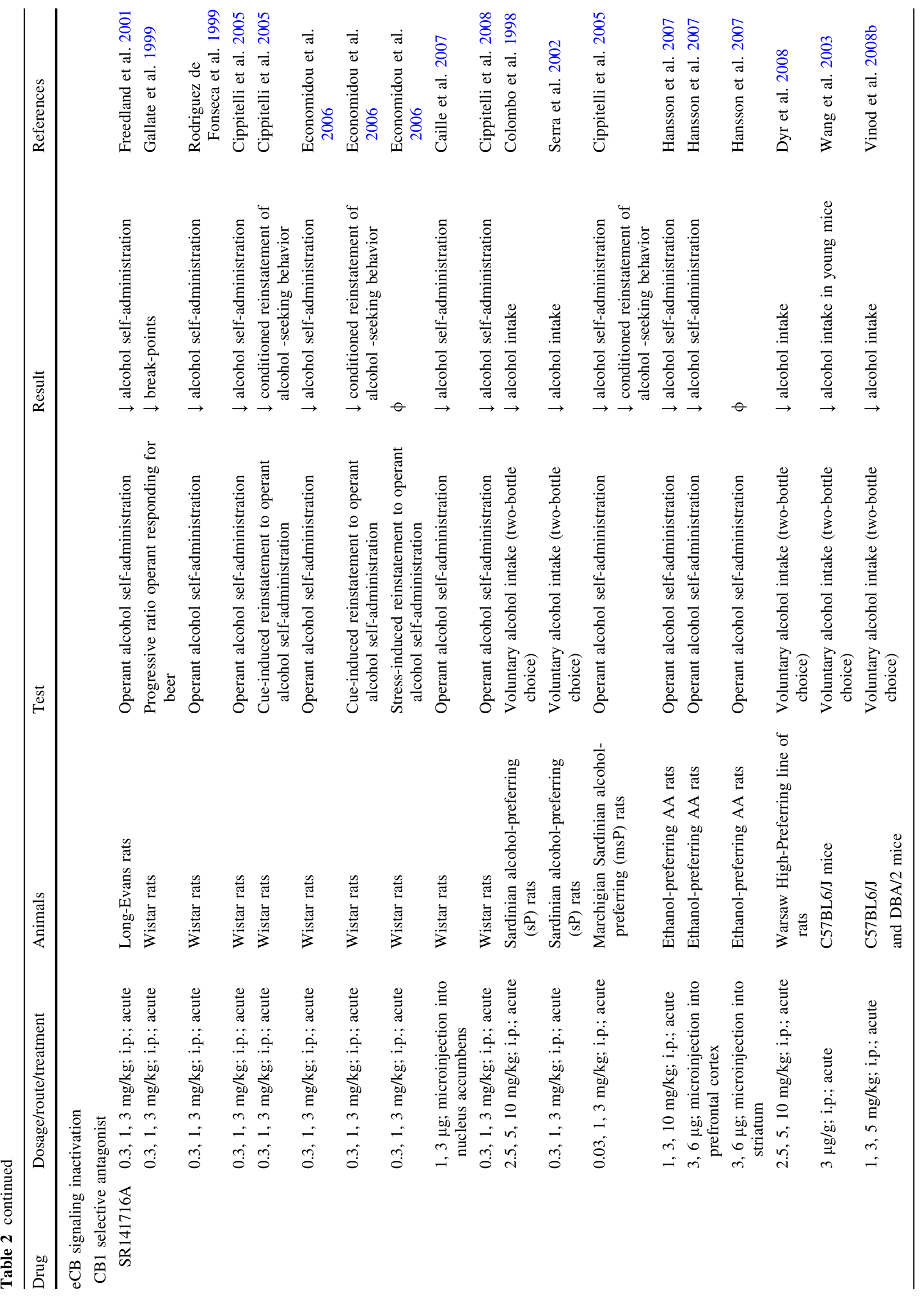




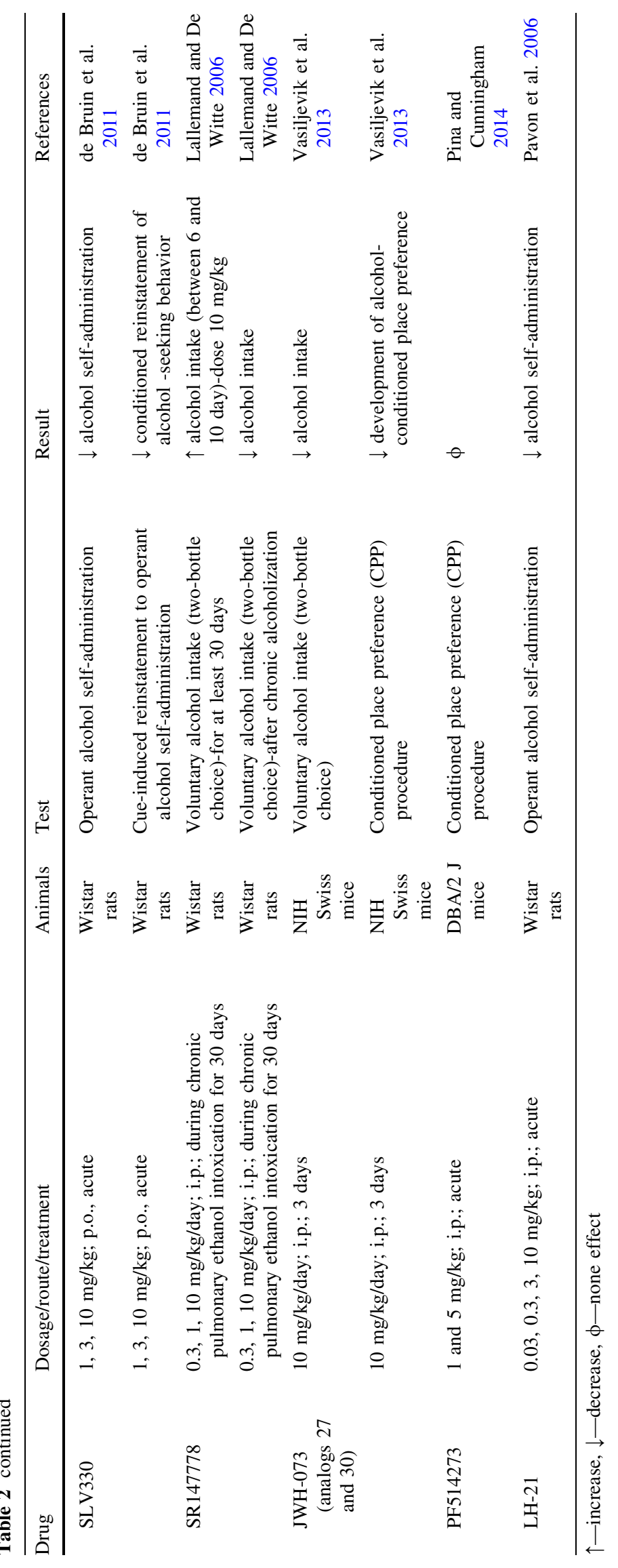


In contrast with cannabinoid agonists, cannabinoid antagonists produce opposite effects, which mediate reduction in alcohol consumption. This conclusion is based on several observations using cannabinoid antagonists. SR141716A (rimonabant), a potent and selective $\mathrm{CB}_{1}$ antagonist, is one of the most well studied compounds and presents a link between cannabinoid receptors and alcohol consumption. The strong ability of this compound to inhibit or reduce the consumption of ethanol has been reported in alcohol-preferring rat strains, such as Sardinian alcoholpreferring (sP) rats (Colombo et al. 1998; Serra et al. 2002), Marchigian Sardinian alcohol-preferring (msP) rats (Cippitelli et al. 2005), alcohol-preferring AA rats (Hansson et al. 2007), and Warsaw High-Preferring rats (Dyr et al. 2008). Furthermore, in alcohol-preferring AA rats, a microinjection of SR141716A into the medial prefrontal cortex reduced alcohol self-administration, while microinjections into the dorsal striatum did not change the number of active lever responses for alcohol (Hansson et al. 2007). In another study, a reduction of alcohol self-administration was observed upon microinjection of SR141716A into the nucleus accumbens (Caille et al. 2007). Alcohol-preferring mice $(\mathrm{C} 57 \mathrm{BL} / 6 \mathrm{~J})$ with a genetic deletion of the functional copies of the $\mathrm{CB}_{1}$ gene demonstrated a decrease in voluntary alcohol intake comparable to pharmacological blockade using SR141716A administration in these mice (Vinod et al. 2008b; Wang et al. 2003). The reduced alcohol self-administration was also observed in rats after acute SR141716A administration (Cippitelli et al. 2005; Economidou et al. 2006; Freedland et al. 2001; Rodriguez de Fonseca et al. 1999) with reduced conditioned reinstatement of alcohol-seeking behavior (Cippitelli et al. 2005; Economidou et al. 2006). The recent study by Marinho et al. (2014) revealed that rimonabant abolished total and peripheral locomotion only at the dose of $10 \mathrm{mg} /$ $\mathrm{kg}$, while lower doses did not affect alcohol-induced hyperlocomotion (Marinho et al. 2014). Nevertheless, similar inhibitory activity and effectiveness was also observed after administration of other $\mathrm{CB}_{1}$ receptor antagonists: i) SVL330, which attenuated alcohol self-administration and reinstatement to alcohol-seeking behaviors in rats (de Bruin et al. 2011); and ii) SR147778, which reduced alcohol preference during cessation of chronic ethanol intoxication but not when co-administered with alcohol (Lallemand and De Witte 2006). This opposing behavior of SR147778 seemed to be similar to that observed for rimonabant. However, significant differences (e.g., induction of a shorter transient increase of alcohol intake) were noted. Additionally, Vasiljevik et al. (2013) reported that two of analogs of a monohydroxylated metabolite of the synthetic aminoalkylindole cannabinoid JHW-073 were shown to decrease alcohol self-administration and alcohol CPP, and, unlike rimonabant, they did not alter body weight during the treatment period (Vasiljevik et al. 2013). However, the ability to inhibit alcohol consumption was not reported for a novel $\mathrm{CB}_{1}$ receptor antagonist, PF514273, which did not reduce the acquisition or expression of alcohol-induced CPP (Pina and Cunningham 2014). On the other hand, LH-21 reduced alcohol self-administration (Pavon et al. 2006). Although the main interest is focused on the inhibitory activity of cannabinoids on alcohol abuse, their other potential therapeutic properties have been presented. The study conducted by Jeong's group (2008) has indicated that a $\mathrm{CB}_{1}$ antagonist may slow down the development of alcohol fatty liver disease and thus prevent or delay its progression to more severe and irreversible forms (Jeong et al. 2008). Yang et al. (2014) proposed administration of CBD to prevent the liver damage caused by alcohol abuse. Additionally, eCB stimulation produced a neuroprotective effect on excitotoxicity induced by the cessation of chronic alcohol consumption (Rubio et al. 2011). Indeed, it has been reported that administration of $\mathrm{HU}-210, \mathrm{a}_{1}$ receptor agonist, induced a significant protection against NMDA-induced cell death during either alcohol withdrawal or alcohol exposure, while chronic administration of a $\mathrm{CB}_{1}$ antagonist aggravated neuronal death induced by NMDA (Rubio et al. 2011) (Table 2). On the whole, these data point to the potential therapeutic application of $\mathrm{CB}$ antagonists in alcohol abuse.

\section{Clinical Studies}

As described above, preclinical studies provide a vast body of evidence suggesting the potential use of the $\mathrm{CB}_{1}$ antagonists in the treatment of alcohol abuse. Unfortunately, the response of alcoholic patients to rimonabant treatment was not so beneficial. Soyka et al. (2008) examined the effect of rimonabant (20 mg per day for 12 weeks) on the rate of relapse among recently detoxified alcoholic individuals and found that rimonabant was ineffective in preventing relapse (Soyka et al. 2008). In the line with this trial, another study using rimonabant (20 mg per day for 2 weeks) in non-treatment-seeking heavy alcohol drinkers demonstrated no effect of this drug on alcohol consumption (George et al. 2010). These two groups failed to find significant differences between rimonabant and placebo in the experiments determining drug impact either on the time to first drink and relapse to heavy drinking or on overall consumption. Several aspects of this lack of effectiveness were considered, such as incorrect administration and small numbers of clinical subjects. However, in consequence, considering an analogical study with naltrexone used at higher doses of 50-150 mg/day, which significantly decreased the consumption of alcohol (Weerts et al. 2008), and the fact that both cannabinoids and naltrexone are inhibitors of the mesolimbic dopamine reward system, it has been suggested 
that rimonabant used at a dose $20 \mathrm{mg} /$ day only partially blocked the $\mathrm{CB}_{1}$ receptor. Therefore, a suggestion was put forth that a significant decrease in the motivation to drink alcohol can occur only as a result of a complete blockade of the signaling associated with the reward system (Cippitelli et al. 2005).

In human clinical studies, marijuana was found to exert some beneficial effects. A prospective study of heavy drinkers revealed that administration of cannabis (marijuana) reduced alcohol consumption faster than in noncannabis users (Metrik et al. 2011). Marijuana and some cannabinoid ligands are known to have influence not only on the consumption of alcohol but also on several effects related with alcohol. Marijuana has been shown to decrease the risk of head neck cancer among moderate tobacco smokers and light alcohol drinkers (Liang et al. 2009).

\section{Adverse Effects Induced by a Combination of Cannabinoid Ligands and Alcohol}

Alcohol abuse is one of the main causes of death and disability in developed countries. Together with cannabinoids, it is considered to be one of the most popular drugs among recreational users. There are explicit similarities between acute effects of ethanol and cannabinoids (Hungund and Basavarajappa 2000). At low doses, both stimulate activity and euphoria, whereas at high doses they produce sedation, and lack of motor coordination (Hungund and Basavarajappa 2000), even if the levels of the consumed doses at which these effects take place differ. Several behavioral and pharmacological effects induced by alcohol have been shown to be the same as those produced by THC. An intake of these substances induces a disruption of spatial learning (Cha et al. 2006), motor dysfunction (Dar 2014), and analgesia (Chiou et al. 2013).

Alcohol and cannabinoids consumed separately lead to several undesirable side effects. Alcohol is found to produce various effects depending on the dosage and duration of its consumption. Low doses of alcohol elicit appetitive gustatory responses that improve the taste of beverages, such as beer or wine (Lemon et al. 2004). In addition, small amounts of alcohol improve mood and generally reduce anxiety. On the contrary, long-term drinking of higher doses of alcohol results in memory impairment, sedation, motor incoordination, confusion, hypothermia, and sometimes vomiting (Gordon and Devinsky 2001; White 2003; Zoethout et al. 2011). Some individuals who are heavy chronic drinkers are at risk of coma and death caused mainly by respiratory depression (Vonghia et al. 2008). Additionally, alcohol is a well known substance most strongly associated with aggression (Hoaken and Stewart 2003), liver diseases, as well as cardiomyopathy (Klatsky 2007).
Similar to alcohol, both endogenous cannabinoids and synthetic $\mathrm{CB}_{1}$ receptor agonists are well known to impair learning skills and memory (Croft et al. 2001). Moreover, acute intoxication with cannabis leads to transient episodes of confusion, depersonalization, paranoid delusions, hallucinations, blunted affect, anxiety, and agitation (Fernandez-Espejo et al. 2009). In addition to these variety of effects, the consumption of cannabis affects psychomotor activity (McLaughlin et al. 2000).

Although some have found no acute addictive effects of co-administered cannabinoids and alcohol, it is postulated that such a combination may enhance some of their inherent adverse effects.

\section{Preclinical Studies}

There are several lines of evidence confirming a synergic action of $\Delta^{9}$-THC and alcohol, which increase the risk of their co-administration. One study reporting side effects resulting from concomitant alcohol and marijuana use was presented by Ciccocioppo et al. (2002), who demonstrated that memory disturbances might be aggravated by a coadministration of cannabinoids and alcohol. In fact, a significant impairment of object recognition was observed in $\mathrm{msP}$ rats injected with $\Delta^{9}$-THC (at a dose of $10 \mathrm{mg} / \mathrm{kg}$, i.p.) after alcohol intake, while lower doses did not change this parameter (Ciccocioppo et al. 2002). It was also observed that intracerebellar injection of $\Delta^{9}$-THC antagonized alcohol-induced ataxia following alcohol consumption in mice (Dar 2014).

\section{Clinical Studies}

It has been shown that both alcohol and marijuana use resulted in significant changes in brain structures as well as abnormal brain functioning, which were much more serious than those produced by each substance separately. These changes mostly affect the hippocampus, which when damaged, may lead to deficits in verbal and visual memory, working memory, visuospatial functioning, gait/balance, reasoning, response perseveration, and processing speed (Aasly et al. 1993; Gillet et al. 2001; Lisdahl et al. 2013; Medina et al. 2007; Tapert et al. 2002). Recent studies by Winward et al. (2014) have shown that concomitant use of marijuana and alcohol during adolescence evoked decrements in cognitive functioning and poor performance in specific cognitive domains. Additionally, differences in verbal recall as well as in cognitive flexibility were observed even after a month of abstinence from concomitant use of marijuana and alcohol in comparison with the control group (Winward et al. 2014). Surprisingly, considering the structural changes of the hippocampus, it was reported that individuals using a combination of these two 
substances did not differ from non-substance using controls in hippocampal asymmetry or volume, which was explained by the specific mechanism of marijuana alone (Medina et al. 2007). Such buffering action of cannabinoids on the negative effects of alcohol on the brain was also shown by Mahmood et al. (2010) who indicated no relation between visual learning or memory performance and alcohol hangover/withdrawal in cannabis-using adolescents (Mahmood et al. 2010). Additionally, cumulative acute effects of $\Delta^{9}$-THC or CBD and alcohol in perceptual and motor function have been found (Belgrave et al. 1979; Bramness et al. 2010; Chait and Perry 1994; Consroe et al. 1979). The combination of these drugs is also well known to increase reaction time and the number of incorrect responses to emergencies (Bramness et al. 2010). Several studies have found additive or multiplicative effects of marijuana and alcohol on causing road accidents (Bramness et al. 2010; Ramaekers et al. 2000). Dubois et al. (2014) reported that drivers positive for both substances had a greater likelihood of making errors than drivers positive for either alcohol or cannabis alone (Dubois et al. 2014). This was observed in parallel with the study by Bramness et al. (2010), who revealed that simultaneous application of both substances impaired driving ability, thus markedly increasing the risk of being judged impaired (Bramness et al. 2010). Additionally, Ronen et al. (2010) reported that during driving tests, either heart rate remained higher or greater sensations of fatigue and sleepiness over time were observed after administration of the combination of these two drugs (Ronen et al. 2010). However, it has been suggested that driving performance affected by both alcohol and THC consumption depends on the doses of both substances as well as on the drug-use history of the individual, and thus, this issue still remains inconclusive. It is worthwhile to note that a combination of cannabinoids and cannabis-like substances with alcohol may induce aggressive behavior. This assumption is based on the findings of Pennings et al. (2002) who reported that aggressive behavior may be magnified when alcohol and other illicit drugs (such as cocaine) are combined (Pennings et al. 2002). On the other hand, Easton et al. (2007), while examining the differences between an alcohol alone group and an alcohol + drug (cocaine or marijuana) group, noticed that the participants who combined alcohol with another drug had problems with anger management (increases in angry feelings and anger expression such as slamming doors). However, this did not result in physical violence against their partners or other people (Easton et al. 2007). Indeed, a recent study by Korcha et al. (2014) confirmed these assumptions by showing that in subjects who reported using a combination of alcohol and drugs (marijuana), men were seven times more likely and women were four times more likely to report a violence-related injury compared with those reporting no use of either alcohol or drugs prior to injury (Korcha et al. 2014). A recently published article by Kelly et al. (2015) has suggested that mid-adolescent subjects (14-15 years old) characterized as polydrug users (mainly alcohol and cannabis users) are at an elevated risk of school non-completion (Kelly et al. 2015).

Interestingly, while cannabinoid ligands may serve as a useful tool for reduction of alcohol withdrawal symptoms, it has been revealed that cannabis abstinence leads to significant increases in alcohol consumption among those with a previous alcohol dependence diagnosis or those with low alcohol consumption at baseline (Allsop et al. 2014; Peters and Hughes 2010). This was in agreement with the previous findings of Midanik et al. (2007) who reported that concurrent alcohol and marijuana users were not only characterized by a greater alcohol dependence but also experienced greater social consequences and depression (Midanik et al. 2007). Furthermore, Osilla et al. (2014) have shown that people using both marijuana and alcohol reported increased alcohol consumption, both with regards to frequency and quantity, as well as greater alcohol-related consequences and prescription drug misuse (Osilla et al. 2014).

\section{Conclusions}

In this review, we focused on beneficial and adverse effects resulting from a combination of well-known and widely used psychoactive stimulants: alcohol and cannabinoids.

According to presented data, the magnitude of potential side effects induced by these two substances seems to dominate,. There are several reports demonstrating that a co-administration of cannabinoid receptor antagonists and alcohol may be a highly effective therapy for alcohol abuse. However, this effect only applies to animal studies because rimonabant, for example, failed to be active in human studies. While its administration to animals resulted in a significant reduction in alcohol consumption and an attenuation of alcohol-induced hyperlocomotion, the application of rimonabant to patients (either detoxified or non-treated heavy alcohol drinkers) revealed to have no effect on drinking. Importantly, rimonabant has been withdrawn from the market due to potentially serious side effects. Therefore, even if its intake were proved to be beneficial in terms of reduction of alcohol consumption or inhibition of alcohol withdrawal symptoms, this drug would require supervised use. Interestingly, the use of cannabinoid receptors antagonists in animals is unclear. It has been shown that different antagonists exert different, and sometimes opposite, effects (see: AM630, PF514273, and LH-21). Additionally, drug distribution and affected 
brain area were found to be of a great importance. Moreover, with regard to cannabinoid receptor agonists, data presented for clinical and preclinical studies indicated a surprising difference in action. A great example is marijuana, which intensifies the desire to drink alcohol in animals but reduces alcohol consumption in human cannabis users. This is consistent with the overall sentiment based on various preclinical studies in rodents that the pharmacological blockade or genetic ablation of $\mathrm{CB}_{1}$ receptors decreased operant selfadministration of alcohol and its voluntary consumption. Furthermore, the activation of $\mathrm{CB}_{1}$ receptors facilitates alcohol consumption while antagonism of $\mathrm{CB}_{1}$ receptor reduces the motivational properties of alcohol.

In light of this highly inconsistent information and the fact that results obtained in animals do not necessary translate into human studies, it is very difficult to unanimously say that cannabinoid drugs may be useful in human therapy. This, however, may change thanks to novel pharmacological strategies involving the use of $\mathrm{CB}_{2}$ receptor agonists. Although, their role in the treatment of alcohol dependence is still under investigation and a development of a drug that possesses the same activity both in animals and human is greatly needed, $\mathrm{CB}_{2}$ agonists (particularly highly selective ones) may be much more useful than $\mathrm{CB}_{1}$ ligands due to the lack of psychotropic effects mediated by cannabinoid 1 receptors, despite the fact that $\mathrm{CB}_{1}$ antagonism appeared to be favorable for the treatment of alcohol dependence.

Acknowledgement This study was supported by the research Grant UMO-2012/05/B/NZ7/02589 from the National Science Centre, Cracow, Poland and by statutory funds from the Jagiellonian University (K/ZDS/004127).

\section{Compliance with Ethical Standards}

Conflict of interest The authors declare no conflicts of interest.

Open Access This article is distributed under the terms of the Creative Commons Attribution 4.0 International License (http://creative commons.org/licenses/by/4.0/), which permits unrestricted use, distribution, and reproduction in any medium, provided you give appropriate credit to the original author(s) and the source, provide a link to the Creative Commons license, and indicate if changes were made.

\section{References}

Aasly J, Storsaeter O, Nilsen G, Smevik O, Rinck P (1993) Minor structural brain changes in young drug abusers. A magnetic resonance study. Acta Neurol Scand 87:210-214

Abush H, Akirav I (2012) Short- and long-term cognitive effects of chronic cannabinoids administration in late-adolescence rats. PLoS One 7:e31731

Agudelo M, Yndart A, Morrison M, Figueroa G, Munoz K, Samikkannu T, Nair MP (2013) Differential expression and functional role of cannabinoid genes in alcohol users. Drug Alcohol Depend 133:789-793
Ahn K, McKinney MK, Cravatt BF (2008) Enzymatic pathways that regulate endocannabinoid signaling in the nervous system. Chem Rev 108:1687-1707

Alen F, Santos A, Moreno-Sanz G, Gonzalez-Cuevas G, Gine E, Franco-Ruiz L, Navarro M, Lopez-Moreno JA (2009) Cannabinoid-induced increase in relapse-like drinking is prevented by the blockade of the glycine-binding site of $N$-methyl-D-aspartate receptors. Neuroscience 158:465-473

Allsop DJ, Dunlop AJ, Saddler C, Rivas GR, McGregor IS, Copeland J (2014) Changes in cigarette and alcohol use during cannabis abstinence. Drug Alcohol Depend 138:54-60

Ameri A (1999) The effects of cannabinoids on the brain. Prog Neurobiol 58:315-348

Arnold JC, Topple AN, Hunt GE, McGregor IS (1998) Effects of preexposure and co-administration of the cannabinoid receptor agonist CP 55,940 on behavioral sensitization to cocaine. Eur J Pharmacol 354:9-16

Basavarajappa BS, Hungund BL (1999a) Chronic ethanol increases the cannabinoid receptor agonist anandamide and its precursor $\mathrm{N}$-arachidonoylphosphatidylethanolamine in SK-N-SH cells. J Neurochem 72:522-528

Basavarajappa BS, Hungund BL (1999b) Down-regulation of cannabinoid receptor agonist-stimulated [35S]GTP gamma S binding in synaptic plasma membrane from chronic ethanol exposed mouse. Brain Res 815:89-97

Basavarajappa BS, Cooper TB, Hungund BL (1998a) Chronic ethanol administration down-regulates cannabinoid receptors in mouse brain synaptic plasma membrane. Brain Res 793:212-218

Basavarajappa BS, Cooper TB, Hungund BL (1998b) Effect of chronic ethanol exposure on mouse brain arachidonic acid specific phospholipase A2. Biochem Pharmacol 55:515-521

Basavarajappa BS, Saito M, Cooper TB, Hungund BL (2000a) Stimulation of cannabinoid receptor agonist 2-arachidonoylglycerol by chronic ethanol and its modulation by specific neuromodulators in cerebellar granule neurons. Biochim Biophys Acta $1535: 78-86$

Basavarajappa BS, Saito M, Cooper TB, Hungund BL (2000b) Stimulation of cannabinoid receptor agonist 2-arachidonylglycerol by chronic ethanol and its modulation by specific neuromodulators in cerebellar granule neurons. Biochim Biophys Acta 1535:78-86

Basavarajappa BS, Saito M, Cooper TB, Hungund BL (2003) Chronic ethanol inhibits the anandamide transport and increases extracellular anandamide levels in cerebellar granule neurons. Eur J Pharmacol 466:73-83

Basavarajappa BS, Yalamanchili R, Cravatt BF, Cooper TB, Hungund BL (2006) Increased ethanol consumption and preference and decreased ethanol sensitivity in female FAAH knockout mice. Neuropharmacology 50:834-844

Basavarajappa BS, Ninan I, Arancio O (2008) Acute ethanol suppresses glutamatergic neurotransmission through endocannabinoids in hippocampal neurons. J Neurochem 107: 1001-1013

Baum-Baicker C (1985) The psychological benefits of moderate alcohol consumption: a review of the literature. Drug Alcohol Depend 15:305-322

Beal JE, Olson R, Laubenstein L, Morales JO, Bellman P, Yangco B, Lefkowitz L, Plasse TF, Shepard KV (1995) Dronabinol as a treatment for anorexia associated with weight loss in patients with AIDS. J Pain Symptom Manage 10:89-97

Belgrave BE, Bird KD, Chesher GB, Jackson DM, Lubbe KE, Starmer GA, Teo RK (1979) The effect of (-) trans-delta9tetrahydrocannabinol, alone and in combination with ethanol, on human performance. Psychopharmacology 62:53-60

Blednov YA, Cravatt BF, Boehm SL 2nd, Walker D, Harris RA (2007) Role of endocannabinoids in alcohol consumption and 
intoxication: studies of mice lacking fatty acid amide hydrolase. Neuropsychopharmacology 32:1570-1582

Borrelli F, Fasolino I, Romano B, Capasso R, Maiello F, Coppola D, Orlando P, Battista G, Pagano E, Di Marzo V, Izzo AA (2013) Beneficial effect of the non-psychotropic plant cannabinoid cannabigerol on experimental inflammatory bowel disease. Biochem Pharmacol 85:1306-1316

Bramness JG, Khiabani HZ, Morland J (2010) Impairment due to cannabis and ethanol: clinical signs and additive effects. Addiction 105:1080-1087

Bystrowska B, Smaga I, Frankowska M, Filip M (2014) Changes in endocannabinoid and $\mathrm{N}$-acylethanolamine levels in rat brain structures following cocaine self-administration and extinction training. Prog Neuropsychopharmacol Biol Psychiatry 50:1-10

Caille S, Alvarez-Jaimes L, Polis I, Stouffer DG, Parsons LH (2007) Specific alterations of extracellular endocannabinoid levels in the nucleus accumbens by ethanol, heroin, and cocaine selfadministration. J Neurosci 27:3695-3702

Cha YM, White AM, Kuhn CM, Wilson WA, Swartzwelder HS (2006) Differential effects of delta9-THC on learning in adolescent and adult rats. Pharmacol Biochem Behav 83:448-455

Chait LD, Perry JL (1994) Acute and residual effects of alcohol and marijuana, alone and in combination, on mood and performance. Psychopharmacology 115:340-349

Chiou LC, Hu SS, Ho YC (2013) Targeting the cannabinoid system for pain relief? Acta Anaesthesiol Taiwan 51:161-170

Christensen R, Kristensen PK, Bartels EM, Bliddal H, Astrup A (2007) Efficacy and safety of the weight-loss drug rimonabant: a meta-analysis of randomised trials. Lancet 370:1706-1713

Ciccocioppo R, Antonelli L, Biondini M, Perfumi M, Pompei P, Massi M (2002) Memory impairment following combined exposure to delta(9)-tetrahydrocannabinol and ethanol in rats. Eur J Pharmacol 449:245-252

Cippitelli A, Bilbao A, Hansson AC, del Arco I, Sommer W, Heilig M, Massi M, Bermudez-Silva FJ, Navarro M, Ciccocioppo R, Rodriguez de Fonseca F (2005) Cannabinoid CB1 receptor antagonism reduces conditioned reinstatement of ethanol-seeking behavior in rats. Eur J Neurosci 21:2243-2251

Cippitelli A, Bilbao A, Gorriti MA, Navarro M, Massi M, Piomelli D, Ciccocioppo R, Rodriguez de Fonseca F (2007) The anandamide transport inhibitor AM404 reduces ethanol self-administration. Eur J Neurosci 26:476-486

Cippitelli A, Cannella N, Braconi S, Duranti A, Tontini A, Bilbao A, Rodriguez de Fonseca F, Piomelli D, Ciccocioppo R (2008) Increase of brain endocannabinoid anandamide levels by FAAH inhibition and alcohol abuse behaviours in the rat. Psychopharmacology 198:449-460

Colombo G, Agabio R, Fa M, Guano L, Lobina C, Loche A, Reali R, Gessa GL (1998) Reduction of voluntary ethanol intake in ethanol-preferring $\mathrm{sP}$ rats by the cannabinoid antagonist SR141716. Alcohol 33:126-130

Colombo G, Serra S, Brunetti G, Gomez R, Melis S, Vacca G, Carai MM, Gessa L (2002) Stimulation of voluntary ethanol intake by cannabinoid receptor agonists in ethanol-preferring $\mathrm{sP}$ rats. Psychopharmacology 159:181-187

Consroe P, Carlini EA, Zwicker AP, Lacerda LA (1979) Interaction of cannabidiol and alcohol in humans. Psychopharmacology 66:45-50

Consroe P, Sandyk R, Snider SR (1986) Open label evaluation of cannabidiol in dystonic movement disorders. Int $\mathrm{J}$ Neurosci 30:277-282

Croft RJ, Mackay AJ, Mills AT, Gruzelier JG (2001) The relative contributions of ecstasy and cannabis to cognitive impairment. Psychopharmacology 153:373-379

Dar MS (2014) Functional interaction and cross-tolerance between ethanol and Delta9-THC: possible modulation by mouse cerebellar adenosinergic A1/GABAergic-A receptors. Behav Brain Res 270:287-294

de Bruin NM, Lange JH, Kruse CG, Herremans AH, Schoffelmeer AN, van Drimmelen M, De Vries TJ (2011) SLV330, a cannabinoid $\mathrm{CB}(1)$ receptor antagonist, attenuates ethanol and nicotine seeking and improves inhibitory response control in rats. Behav Brain Res 217:408-415

Devane WA, Dysarz FA 3rd, Johnson MR, Melvin LS, Howlett AC (1988) Determination and characterization of a cannabinoid receptor in rat brain. Mol Pharmacol 34:605-613

Devane WA, Hanus L, Breuer A, Pertwee RG, Stevenson LA, Griffin G, Gibson D, Mandelbaum A, Etinger A, Mechoulam R (1992) Isolation and structure of a brain constituent that binds to the cannabinoid receptor. Science 258:1946-1949

Dubois S, Mullen N, Weaver B, Bedard M (2014) The combined effects of alcohol and cannabis on driving: impact on crash risk. Forensic Sci Int 248c:94-100

Dyr W, Ligieza J, Kostowski W (2008) The effect of cannabinoid $\mathrm{CB}(1)$ receptor antagonist rimonabant (SR-141716) on ethanol drinking in high-preferring rats. Alcohol 42:509-512

Easton CJ, Mandel D, Babuscio T, Rounsaville BJ, Carroll KM (2007) Differences in treatment outcome between male alcohol dependent offenders of domestic violence with and without positive drug screens. Addict Behav 32:2151-2163

Economidou D, Mattioli L, Cifani C, Perfumi M, Massi M, Cuomo V, Trabace L, Ciccocioppo R (2006) Effect of the cannabinoid CB1 receptor antagonist SR-141716A on ethanol self-administration and ethanol-seeking behaviour in rats. Psychopharmacology 183:394-403

Erdozain AM, Callado LF (2011) Involvement of the endocannabinoid system in alcohol dependence: The biochemical, behavioral and genetic evidence. Drug Alcohol Depend 117:102-110

Fernandez-Espejo E, Viveros MP, Nunez L, Ellenbroek BA, Rodriguez de Fonseca F (2009) Role of cannabis and endocannabinoids in the genesis of schizophrenia. Psychopharmacology 206:531-549

Fernandez-Lopez D, Pradillo JM, Garcia-Yebenes I, Martinez-Orgado JA, Moro MA, Lizasoain I (2010) The cannabinoid WIN55212-2 promotes neural repair after neonatal hypoxia-ischemia. Stroke 41:2956-2964

Ferrer B, Bermudez-Silva FJ, Bilbao A, Alvarez-Jaimes L, SanchezVera I, Giuffrida A, Serrano A, Baixeras E, Khaturia S, Navarro M, Parsons LH, Piomelli D, Rodriguez de Fonseca F (2007) Regulation of brain anandamide by acute administration of ethanol. Biochem J 404:97-104

Formukong EA, Evans AT, Evans FJ (1988) Analgesic and antiinflammatory activity of constituents of cannabis Sativa L. Inflammation 4:361-371

Freedland CS, Poston JS, Porrino LJ (2000) Effects of SR141716A, a central cannabinoid receptor antagonist, on food-maintained responding. Pharmacol Biochem Behav 67:265-270

Freedland CS, Sharpe AL, Samson HH, Porrino LJ (2001) Effects of SR141716A on ethanol and sucrose self-administration. Alcohol Clin Exp Res 25:277-282

Gallate JE, Saharov T, Mallet PE, McGregor IS (1999) Increased motivation for beer in rats following administration of a cannabinoid CB1 receptor agonist. Eur J Pharmacol 370:233-240

George DT, Herion DW, Jones CL, Phillips MJ, Hersh J, Hill D, Heilig M, Ramchandani VA, Geyer C, Spero DE, Singley ED, O'Malley SS, Bishai R, Rawlings RR, Kunos G (2010) Rimonabant (SR141716) has no effect on alcohol self-administration or endocrine measures in nontreatment-seeking heavy alcohol drinkers. Psychopharmacology 208:37-44

Gillet C, Polard E, Mauduit N, Allain H (2001) Acting out and psychoactive substances: alcohol, drugs, illicit substances. Encephale 27:351-359 
Gong JP, Onaivi ES, Ishiguro H, Liu QR, Tagliaferro PA, Brusco A, Uhl GR (2006) Cannabinoid CB2 receptors: immunohistochemical localization in rat brain. Brain Res 107:10-23

Gonzalez S, Cascio MG, Fernandez-Ruiz J, Fezza F, Di Marzo V, Ramos JA (2002a) Changes in endocannabinoid contents in the brain of rats chronically exposed to nicotine, ethanol or cocaine. Brain Res 954:73-81

Gonzalez S, Fernandez-Ruiz J, Sparpaglione V, Parolaro D, Ramos JA (2002b) Chronic exposure to morphine, cocaine or ethanol in rats produced different effects in brain cannabinoid $\mathrm{CB}(1)$ receptor binding and mRNA levels. Drug Alcohol Depend 66:77-84

Gonzalez S, Fernández-Ruiz JJ, Sparpaglione V, Parolaro D, Ramos JA (2002c) Chronic exposure to morphine, cocaine or ethanol in rats produced different effects in brain cannabinoid CB1 receptor binding and mRNA levels. Drug Alcohol Depend 66:77-84

Gonzalez S, Cebeira M, Fernandez-Ruiz J (2005) Cannabinoid tolerance and dependence: a review of studies in laboratory animals. Pharmacol Biochem Behav 81:300-318

Gordon E, Devinsky O (2001) Alcohol and marijuana: effects on epilepsy and use by patients with epilepsy. Epilepsia 42:1266-1272

Gutierrez-Lopez MD, Llopis N, Feng S, Barrett DA, O'Shea E, Colado MI (2010) Involvement of 2-arachidonoyl glycerol in the increased consumption of and preference for ethanol of mice treated with neurotoxic doses of methamphetamine. $\mathrm{Br} \mathrm{J}$ Pharmacol 160:772-783

Hansen HS, Moesgaard B, Hansen HH, Petersen G (2000) NAcylethanolamines and precursor phospholipids-relation to cell injury. Chem Phys Lipids 108:135-150

Hansson AC, Bermudez-Silva FJ, Malinen H, Hyytia P, SanchezVera I, Rimondini R, Rodriguez de Fonseca F, Kunos G, Sommer WH, Heilig M (2007) Genetic impairment of frontocortical endocannabinoid degradation and high alcohol preference. Neuropsychopharmacology 32:117-126

Herkenham M, Lynn AB, Johnson MR, Melvin LS, de Costa BR, Rice KC (1991) Characterization and localization of cannabinoid receptors in rat brain: a quantitative in vitro autoradiographic study. J Neurosci 11:563-583

Hildebrandt AL, Kelly-Sullivan DM, Black SC (2003) Antiobesity effects of chronic cannabinoid $\mathrm{CB} 1$ receptor antagonist treatment in diet-induced obese mice. Eur J Pharmacol 462:125-132

Hoaken PN, Stewart SH (2003) Drugs of abuse and the elicitation of human aggressive behavior. Addict Behav 28:1533-1554

Hohmann AG, Herkenham M (2000) Localization of cannabinoid $\mathrm{CB}(1)$ receptor mRNA in neuronal subpopulations of rat striatum: a double-label in situ hybridization study. Synapse 37:71-80

Houchi H, Babovic D, Pierrefiche O, Ledent C, Daoust M, Naassila M (2005) CB1 receptor knockout mice display reduced ethanolinduced conditioned place preference and increased striatal dopamine D2 receptors. Neuropsychopharmacology 30:339-349

Howlett AC, Barth F, Bonner TI, Cabral G, Casellas P, Devane WA, Felder CC, Herkenham M, Mackie K, Martin BR, Mechoulam R, Pertwee RG (2002) International Union of Pharmacology. XXVII. Classification of cannabinoid receptors. Pharmacol Rev 54:161-202

Huang SM, Bisogno T, Petros TJ, Chang SY, Zavitsanos PA, Zipkin RE, Sivakumar R, Coop A, Maeda DY, De Petrocellis L, Burstein S, Di Marzo V, Walker JM (2001) Identification of a new class of molecules, the arachidonyl amino acids, and characterization of one member that inhibits pain. J Biol Chem 276:42639-42644

Hungund BL, Basavarajappa BS (2000) Are anandamide and cannabinoid receptors involved in ethanol tolerance? A review of the evidence. Alcohol Alcohol 35:126-133

Ironside R, Bosanquet FD, McMenemy WH (1961) Central demyelination of the corpus callosum (Marchiafava-Bignami disease). With report of a second case in Great Britain. Brain 84:212-217
Jeong WI, Osei-Hyiaman D, Park O, Liu J, Batkai S, Mukhopadhyay P, Horiguchi N, Harvey-White J, Marsicano G, Lutz B, Gao B, Kunos G (2008) Paracrine activation of hepatic CB1 receptors by stellate cell-derived endocannabinoids mediates alcoholic fatty liver. Cell Metab 7:227-235

Kannel WB, Ellison RC (1996) Alcohol and coronary heart disease: the evidence for a protective effect. Clin Chim Acta 246:59-76

Karniol IG, Shirakawa I, Takahashi RN, Knobel E, Musty RE (1975) Effects of delta9-tetrahydrocannabinol and cannabinol in man. Pharmacology 13:502-512

Kelly AB, Evans-Whipp TJ, Smith R, Chan GC, Toumbourou JW, Patton GC, Hemphill SA, Hall WD, Catalano RF (2015) A longitudinal study of the association of adolescent polydrug use, alcohol use and high school non-completion. Addiction 110: $627-635$

Kinsey SG, Mahadevan A, Zhao B, Sun H, Naidu PS, Razdan RK, Selley DE, Imad Damaj M, Lichtman AH (2011) The CB2 cannabinoid receptor-selective agonist O-3223 reduces pain and inflammation without apparent cannabinoid behavioral effects. Neuropharmacology 60:244-251

Klatsky AL (2007) Alcohol, cardiovascular diseases and diabetes mellitus. Pharmacol Res 55:237-247

Korcha RA, Cherpitel CJ, Witbrodt J, Borges G, Hejazi-Bazargan S, Bond JC, Ye Y, Gmel G (2014) Violence-related injury and gender: the role of alcohol and alcohol combined with illicit drugs. Drug Alcohol Rev 33:43-50

Lallemand F, de Witte P (2005) Ethanol induces higher BEC in CB1 cannabinoid receptor knockout mice while decreasing ethanol preference. Alcohol Alcohol 40:54-62

Lallemand F, De Witte P (2006) SR147778, a CB1 cannabinoid receptor antagonist, suppresses ethanol preference in chronically alcoholized Wistar rats. Alcohol 39:125-134

Lamarque S, Taghzouti K, Simon H (2001) Chronic treatment with Delta(9)-tetrahydrocannabinol enhances the locomotor response to amphetamine and heroin. Implications for vulnerability to drug addiction. Neuropharmacology 41:118-129

Lapoint J, James LP, Moran CL, Nelson LS, Hoffman RS, Moran JH (2011) Severe toxicity following synthetic cannabinoid ingestion. Clin Toxicol (Phila) 49:760-764

Leggett JD, Aspley S, Beckett SR, D’Antona AM, Kendall DA (2004) Oleamide is a selective endogenous agonist of rat and human CB1 cannabinoid receptors. Br J Pharmacol 141:253-262

Lehtonen M, Storvik M, Tupala E, Hyytia P, Tiihonen J, Callaway JC (2010) Endogenous cannabinoids in post-mortem brains of Cloninger type 1 and 2 alcoholics. Eur Neuropsychopharmacol 20:245-252

Lemon CH, Brasser SM, Smith DV (2004) Alcohol activates a sucrose-responsive gustatory neural pathway. J Neurophysiol 92:536-544

Liang C, McClean MD, Marsit C, Christensen B, Peters E, Nelson HH, Kelsey KT (2009) A population-based case-control study of marijuana use and head and neck squamous cell carcinoma. Cancer Prev Res (Phila) 2:759-768

Lile JA, Kelly TH, Hays LR (2010) Substitution profile of the cannabinoid agonist nabilone in human subjects discriminating delta9-tetrahydrocannabinol. Clin Neuropharmacol 33:235-242

Linsenbardt DN, Boehm SL 2nd (2009) Agonism of the endocannabinoid system modulates binge-like alcohol intake in male C57BL/6 J mice: involvement of the posterior ventral tegmental area. Neuroscience 164:424-434

Lisdahl KM, Gilbart ER, Wright NE, Shollenbarger S (2013) Dare to delay? The impacts of adolescent alcohol and marijuana use onset on cognition, brain structure, and function. Front Psychiatry. doi:10.3389/fpsyt.2013.00053

Lopez-Moreno JA, Gonzalez-Cuevas G, Rodriguez de Fonseca F, Navarro M (2004) Long-lasting increase of alcohol relapse by 
the cannabinoid receptor agonist WIN 55,212-2 during alcohol deprivation. J Neurosci 24:8245-8252

Louvet A, Teixeira-Clerc F, Chobert MN, Deveaux V, Pavoine C, Zimmer A, Pecker F, Mallat A, Lotersztajn S (2011) Cannabinoid CB2 receptors protect against alcoholic liver disease by regulating Kupffer cell polarization in mice. Hepatology 54: $1217-1226$

LoVerme J, Duranti A, Tontini A, Spadoni G, Mor M, Rivara S, Stella N, Xu C, Tarzia G, Piomelli D (2009) Synthesis and characterization of a peripherally restricted CB1 cannabinoid antagonist, URB447, that reduces feeding and body-weight gain in mice. Bioorg Med Chem Lett 19:639-643

Machado Rocha FC, Stefano SC, De Cassia Haiek R, Rosa Oliveira LM, Da Silveira DX (2008) Therapeutic use of Cannabis sativa on chemotherapy-induced nausea and vomiting among cancer patients: systematic review and meta-analysis. Eur J Cancer Care (Engl) 17:431-443

Mahmood OM, Jacobus J, Bava S, Scarlett A, Tapert SF (2010) Learning and memory performances in adolescent users of alcohol and marijuana: interactive effects. J Stud Alcohol Drugs 71:885-894

Maida V, Ennis M, Irani S, Corbo M, Dolzhykov M (2008) Adjunctive nabilone in cancer pain and symptom management: a prospective observational study using propensity scoring. J Support Oncol 6:119-124

Marinho EA, Oliveira-Lima AJ, Santos R, Hollais AW, Baldaia MA, Wuo-Silva R, Yokoyama TS, Takatsu-Coleman AL, Patti CL, Longo BM, Berro LF, Frussa-Filho R (2014) Effects of rimonabant on the development of single dose-induced behavioral sensitization to ethanol, morphine and cocaine in mice. Prog Neuropsychopharmacol Biol Psychiatry 58c:22-31

Masten SV, Guenzburger GV (2014) Changes in driver cannabinoid prevalence in 12 U.S. states after implementing medical marijuana laws. J Safety Res 50:35-52

McLaughlin PJ, Delevan CE, Carnicom S, Robinson JK, Brener J (2000) Fine motor control in rats is disrupted by delta-9tetrahydrocannabinol. Pharmacol Biochem Behav 66:803-809

Medina KL, Schweinsburg AD, Cohen-Zion M, Nagel BJ, Tapert SF (2007) Effects of alcohol and combined marijuana and alcohol use during adolescence on hippocampal volume and asymmetry. Neurotoxicol Teratol 29:141-152

Metrik J, Spillane NS, Leventhal AM, Kahler CW (2011) Marijuana use and tobacco smoking cessation among heavy alcohol drinkers. Drug Alcohol Depend 119:194-200

Midanik LT, Tam TW, Weisner C (2007) Concurrent and simultaneous drug and alcohol use: results of the 2000 National Alcohol Survey. Drug Alcohol Depend 90:72-80

Mitrirattanakul S, Lopez-Valdes HE, Liang J, Matsuka Y, Mackie K, Faull KF, Spigelman I (2007) Bidirectional alterations of hippocampal cannabinoid 1 receptors and their endogenous ligands in a rat model of alcohol withdrawal and dependence. Alcohol Clin Exp Res 31:855-867

Moreira FA, Crippa JA (2009) The psychiatric side-effects of rimonabant. Rev Bras Psiquiatr 31:145-153

Moreira FA, Wotjak CT (2010) Cannabinoids and anxiety. Curr Top Behav Neurosci 2:429-450

Morgan CJ, Badway A (2009) Alcohol-induced euphoria: exclusion of serotonin. Alcohol Alcohol 36:22-25

Morisset V, Ahluwalia J, Nagy I, Urban L (2001) Possible mechanisms of cannabinoid-induced antinociception in the spinal cord. Eur J Pharmacol 429:93-100

Müller-Vahl KR, Kolbe H, Schneider U, Emrich HM (1999) Cannabis in movement disorders. Forsch Komplementarmed 3:23-27

Myers J, Shetty N (2008) Going beyond efficacy: strategies for cancer pain management. Curr Oncol 15:S41-S49
Naassila M, Pierrefiche O, Ledent C, Daoust M (2004) Decreased alcohol self-administration and increased alcohol sensitivity and withdrawal in CB1 receptor knockout mice. Neuropharmacology 46:243-253

Nagayama T, Sinor AD, Simon RP, Chen J, Graham SH, Jin K, Greenberg DA (1999) Cannabinoids and neuroprotection in global and focal cerebral ischemia and in neuronal cultures. J Neurosci 19:2987-2995

Narang S, Gibson D, Wasan AD, Ross EL, Michna E, Nedeljkovic SS, Jamison RN (2008) Efficacy of dronabinol as an adjuvant treatment for chronic pain patients on opioid therapy. J Pain 9:254-264

Norstrom T (1998) Effects on criminal violence of different beverage types and private and public drinking. Addiction 93:689-699

Nurmikko TJ, Serpell MG, Hoggart B, Toomey PJ, Morlion BJ, Haines D (2007) Sativex successfully treats neuropathic pain characterised by allodynia: a randomised, double-blind, placebocontrolled clinical trial. Pain 133:210-220

Oka S, Wakui J, Ikeda S, Yanagimoto S, Kishimoto S, Gokoh M, Nasui M, Sugiura T (2006) Involvement of the cannabinoid CB2 receptor and its endogenous ligand 2-arachidonoylglycerol in oxazoloneinduced contact dermatitis in mice. J Immunol 177:8796-8805

Onaivi ES, Ishiguro H, Gong JP, Patel S, Perchuk A, Meozzi PA, Myers L, Mora Z, Tagliaferro P, Gardner E, Brusco A, Akinshola BE, Liu QR, Hope B, Iwasaki S, Arinami T, Teasenfitz L, Uhl GR (2006) Discovery of the presence and functional expression of cannabinoid CB2 receptors in brain. Ann NY Acad Sci 1074:514-536

Onaivi ES, Carpio O, Ishiguro H, Schanz N, Uhl GR, Benno R (2008) Behavioral effects of $\mathrm{CB} 2$ cannabinoid receptor activation and its influence on food and alcohol consumption. Ann NY Acad Sci 1139:426-433

Ortiz S, Oliva JM, Perez-Rial S, Palomo T, Manzanares J (2004) Chronic ethanol consumption regulates cannabinoid CB1 receptor gene expression in selected regions of rat brain. Alcohol Alcohol 39:88-92

Osilla KC, Pedersen ER, Ewing BA, Miles JN, Ramchand R, D'Amico EJ (2014) The effects of purchasing alcohol and marijuana among adolescents at-risk for future substance use. Subst Abuse Treat Prev Policy 9:38

Palmer E (2014) Sativex: 'Life Changing' cannabis-based multiple sclerosis drug rejected for use in England. http://www.ibtimes. co.uk/sativex-life-changing-cannabis-based-multiple-sclerosisdrug-rejected-use-england-1469080. Accessed 8 Oct 2014

Parolaro D, Vigano D, Realini N, Rubino T (2007) Role of endocannabinoids in regulating drug dependence. Neuropsychiatr Dis Treat 3:711-721

Pava MJ, Woodward JJ (2012) A review of the interactions between alcohol and the endocannabinoid system: implications for alcohol dependence and future directions for research. Alcohol 46:185-204

Pava MJ, Blake EM, Green ST, Mizroch BJ, Mulholland PJ, Woodward JJ (2012) Tolerance to cannabinoid-induced behaviors in mice treated chronically with ethanol. Psychopharmacology 219:137-147

Pavon FJ, Bilbao A, Hernandez-Folgado L, Cippitelli A, Jagerovic N, Abellan G, Rodriguez-Franco MA, Serrano A, Macias M, Gomez R, Navarro M, Goya P, Rodriguez de Fonseca F (2006) Antiobesity effects of the novel in vivo neutral cannabinoid receptor antagonist 5-(4-chlorophenyl)-1-(2,4-dichlorophenyl)-3hexyl-1H-1,2,4-triazole-LH 21. Neuropharmacology 51:358-366

Pennings EJ, Leccese AP, Wolff FA (2002) Effects of concurrent use of alcohol and cocaine. Addiction 97:773-783

Peters EN, Hughes JR (2010) Daily marijuana users with past alcohol problems increase alcohol consumption during marijuana abstinence. Drug Alcohol Depend 106:111-118 
Pina MM, Cunningham CL (2014) Effects of the novel cannabinoid CB1 receptor antagonist PF 514273 on the acquisition and expression of ethanol conditioned place preference. Alcohol 48:427-431

Pinder RM, Sandler M (2004) Alcohol, wine and mental health: focus on dementia and stroke. J Pharmacol 18:449-456

Poncelet M, Maruani J, Calassi R, Soubrie P (2003) Overeating, alcohol and sucrose consumption decrease in CB1 receptor deleted mice. Neurosci Lett 343:216-218

Porter AC, Sauer JM, Knierman MD, Becker GW, Berna MJ, Bao J, Nomikos GG, Carter P, Bymaster FP, Leese AB, Felder CC (2002) Characterization of a novel endocannabinoid, virodhamine, with antagonist activity at the $\mathrm{CB} 1$ receptor. J Pharmacol Exp Ther 301:1020-1024

Pridemore WA (2004) Weekend effects on binge drinking and homicide: the social connection between alcohol and violence in Russia. Addiction 99:1034-1041

Ramaekers JG, Robbe HW, O'Hanlon JF (2000) Marijuana, alcohol and actual driving performance. Hum Psychopharmacol 15:551-558

Rimondini R, Arlinde C, Sommer W, Heilig M (2002) Long-lasting increase in voluntary ethanol consumption and transcriptional regulation in the rat brain after intermittent exposure to alcohol. FASEB J 16:27-35

Rinaldi-Carmona M, Barth F, Heaulme M, Shire D, Calandra B, Congy C, Martinez S, Maruani J, Neliat G, Caput D, Ferrara P, Soubrié P, Brelière JC, Le Fur G (1994) SR141716A, a potent and selective antagonist of the brain cannabinoid receptor. FEBS Lett 350:240-244

Rinaldi-Carmona M, Barth F, Millan J, Derocq JM, Casellas P, Congy C, Oustric D, Sarran M, Bouaboula M, Calandra B, Portier M, Shire D, Breliere JC, Le Fur GL (1998) SR 144528, the first potent and selective antagonist of the CB2 cannabinoid receptor. J Pharmacol Exp Ther 284:644-650

Rodriguez de Fonseca F, Roberts AJ, Bilbao A, Koob GF, Navarro M (1999) Cannabinoid receptor antagonist SR141716A decreases operant ethanol self administration in rats exposed to ethanolvapor chambers. Acta Pharmacol Sin 20:1109-1114

Ronen A, Chassidim HS, Gershon P, Parmet Y, Rabinovich A, BarHamburger R, Cassuto Y, Shinar D (2010) The effect of alcohol, THC and their combination on perceived effects, willingness to drive and performance of driving and non-driving tasks. Accid Anal Prev 42:1855-1865

Rubbie D, Alonso G, Duchamp F, Bockaert J, Manzoni OJ (2001) Localization and mechanisms of action of cannabinoid receptors at the glutamatergic synapses of the nucleus accumbens. J Neurosci 21:109-116

Rubio M, McHugh D, Fernandez-Ruiz J, Bradshaw H, Walker JM (2007) Short-term exposure to alcohol in rats affects brain levels of anandamide, other $\mathrm{N}$-acylethanolamines and 2-arachidonoylglycerol. Neurosci Lett 421:270-274

Rubio M, Fernandez-Ruiz J, de Miguel R, Maestro B, Michael Walker J, Ramos JA (2008) CB1 receptor blockade reduces the anxiogenic-like response and ameliorates the neurochemical imbalances associated with alcohol withdrawal in rats. Neuropharmacology 54:976-988

Rubio M, de Miguel R, Fernandez-Ruiz J, Gutierrez-Lopez D, Carai MA, Ramos JA (2009) Effects of a short-term exposure to alcohol in rats on FAAH enzyme and CB1 receptor in different brain areas. Drug Alcohol Depend 99:354-358

Rubio M, Villain H, Docagne F, Roussel BD, Ramos JA, Vivien D, Fernandez-Ruiz J, Ali C (2011) Pharmacological activation/ inhibition of the cannabinoid system affects alcohol withdrawalinduced neuronal hypersensitivity to excitotoxic insults. PLoS One 6:e23690

Ryberg E, Larsson N, Sjogren S, Hjorth S, Hermansson NO, Leonova J, Elebring T, Nilsson K, Drmota T, Greasley PJ (2007) The orphan receptor GPR55 is a novel cannabinoid receptor. Br J Pharmacol 152:1092-1101

Sastre-Garriga J, Vila C, Clissold S, Montalban X (2011) THC and CBD oromucosal spray (Sativex(R)) in the management of spasticity associated with multiple sclerosis. Expert Rev Neurother 11:627-637

Saults JS, Cowan N, Sher KJ, Moreno MV (2007) Differential effects of alcohol on working memory: distinguishing multiple processes. Exp Clin Psychopharmacol 15:576-587

Serra S, Brunetti G, Pani M, Vacca G, Carai MA, Gessa GL, Colombo $\mathrm{G}$ (2002) Blockade by the cannabinoid $\mathrm{CB}(1)$ receptor antagonist, SR 141716, of alcohol deprivation effect in alcoholpreferring rats. Eur J Pharmacol 443:95-97

Shen M, Piser TM, Seybold VS, Thayer SA (1996) Cannabinoid receptor agonists inhibit glutamatergic synaptic transmission in rat hippocampal cultures. J Neurosci 16:4322-4334

Skrabek RQ, Galimova L, Ethans K, Perry D (2008) Nabilone for the treatment of pain in fibromyalgia. J Pain 9:164-173

Smaga I, Bystrowska B, Gawlinski D, Pomierny B, Stankowicz P, Filip M (2014a) Antidepressants and changes in concentration of endocannabinoids and $\mathrm{N}$-acylethanolamines in rat brain structures. Neurotox Res 26:190-206

Smaga I, Bystrowska B, Gawlinski D, Przegalinski E, Filip M (2014b) The endocannabinoid/endovanilloid system and depression. Curr Neuropharmacol 12:462-474

Söderpalm B, Löf E, Ericson M (2009) Mechanistic studies of ethanol's interaction with the mesolimbic dopamine reward system. Pharmacopsychiatry 42:S38-S94

Soyka M, Koller G, Schmidt P, Lesch OM, Leweke M, Fehr C, Gann H, Mann KF (2008) Cannabinoid receptor 1 blocker rimonabant (SR 141716) for treatment of alcohol dependence: results from a placebo-controlled, double-blind trial. J Clin Psychopharmacol 28:317-324

Sugiura T, Kondo S, Sukagawa A, Nakane S, Shinoda A, Itoh K, Yamashita A, Waku K (1995) 2-Arachidonoylglycerol: a possible endogenous cannabinoid receptor ligand in brain. Biochem Biophys Res Commun 215:89-97

Tapert SF, Granholm E, Leedy NG, Brown SA (2002) Substance use and withdrawal: neuropsychological functioning over 8 years in youth. J Int Neuropsychol Soc 8:873-883

Thanos PK, Dimitrakakis ES, Rice O, Gifford A, Volkow ND (2005) Ethanol self-administration and ethanol conditioned place preference are reduced in mice lacking cannabinoid CB1 receptors. Behav Brain Res 164:206-213

Tramèr MR, Carroll D, Campbell FA, Reynolds DJM, Moore RA, McQuay HJ (2001) Cannabinoids for control of chemotherapy induced nausea and vomiting: quantitative systematic review. BMJ 323:16

Tucci SA, Halford JC, Harrold JA, Kirkham TC (2006) Therapeutic potential of targeting the endocannabinoids: implications for the treatment of obesity, metabolic syndrome, drug abuse and smoking cessation. Curr Med Chem 13:2669-2680

Ueda Y, Miyagawa N, Matsui T, Kaya T, Iwamura H (2005) Involvement of cannabinoid $\mathrm{CB}(2)$ receptor-mediated response and efficacy of cannabinoid $\mathrm{CB}(2)$ receptor inverse agonist, JTE907, in cutaneous inflammation in mice. Eur $\mathrm{J}$ Pharmacol 520:164-171

Vandrey R, Stitzer ML, Mintzer MZ, Huestis MA, Murray JA, Lee D (2013) The dose effects of short-term dronabinol (oral THC) maintenance in daily cannabis users. Drug Alcohol Depend 128:64-70

Vasiljevik T, Franks LN, Ford BM, Douglas JT, Prather PL, Fantegrossi WE, Prisinzano TE (2013) Design, synthesis, and biological evaluation of aminoalkylindole derivatives as cannabinoid receptor ligands with potential for treatment of alcohol abuse. J Med Chem 56:4537-4550 
Victor M, Adams RD, Mancall EL (1959) A restricted form of cerebellar cortical degeneration occurring in alcoholic patients. Arch Neurol 1:579-688

Victor M, Adams RD, Collins GH (1971) The Wernicke-Korsakoff syndrome: a clinical and pathological study of 245 patients, 82 with post-mortem examinations. Contemp Neurol Ser 7:1-206

Vinod KY, Arango V, Xie S, Kassir SA, Mann JJ, Cooper TB, Hungund BL (2005) Elevated levels of endocannabinoids and CB1 receptor-mediated G-protein signaling in the prefrontal cortex of alcoholic suicide victims. Biol Psychiatry 57:480-486

Vinod KY, Yalamanchili R, Xie S, Cooper TB, Hungund BL (2006) Effect of chronic ethanol exposure and its withdrawal on the endocannabinoid system. Neurochem Int 49:619-625

Vinod KY, Sanguino E, Yalamanchili R, Manzanares J, Hungund BL (2008a) Manipulation of fatty acid amide hydrolase functional activity alters sensitivity and dependence to ethanol. J Neurochem 104:233-243

Vinod KY, Yalamanchili R, Thanos PK, Vadasz C, Cooper TB, Volkow ND, Hungund BL (2008b) Genetic and pharmacological manipulations of the $\mathrm{CB}(1)$ receptor alter ethanol preference and dependence in ethanol preferring and nonpreferring mice. Synapse 62:574-581

Vinod KY, Kassir SA, Hungund BL, Cooper TB, Mann JJ, Arango V (2010) Selective alterations of the CB1 receptors and the fatty acid amide hydrolase in the ventral striatum of alcoholics and suicides. J Psychiatr Res 44:591-597

Vlachou S, Panagis G (2014) Regulation of brain reward by the endocannabinoid system: a critical review of behavioral studies in animals. Curr Pharm Des 20:2072-2088

Vonghia L, Leggio L, Ferrulli A, Bertini M, Gasbarrini G, Addolorato G (2008) Acute alcohol intoxication. Eur J Intern Med 19:561-567

Wang L, Liu J, Harvey-White J, Zimmer A, Kunos G (2003) Endocannabinoid signaling via cannabinoid receptor 1 is involved in ethanol preference and its age-dependent decline in mice. Proc Natl Acad Sci USA 100:1393-1398
Weerts EM, Kim YK, Wand GS, Dannals RF, Lee JS, Frost JJ, McCaul ME (2008) Differences in delta- and mu-opioid receptor blockade measured by positron emission tomography in naltrexone-treated recently abstinent alcohol-dependent subjects. Neuropsychopharmacology 33:653-665

White AM (2003) What happened? Alcohol, memory blackouts, and the brain. Alcohol Res Health 27:186-196

Wilhelmsen K, Khakpour S, Tran A, Sheehan K, Schumacher M, Xu F, Hellman J (2014) The endocannabinoid/endovanilloid $\mathrm{N}$-arachidonoyl dopamine (NADA) and synthetic cannabinoid WIN55,212-2 abate the inflammatory activation of human endothelial cells. J Biol Chem 289:13079-13100

Wilson-Poe AR, Morgan MM, Aicher SA, Hegarty DM (2012) Distribution of CB1 cannabinoid receptors and their relationship with mu-opioid receptors in the rat periaqueductal gray. Neuroscience 213:191-200

Winward JL, Hanson KL, Tapert SF, Brown SA (2014) Heavy alcohol use, marijuana use, and concomitant use by adolescents are associated with unique and shared cognitive decrements. J Int Neuropsychol Soc 20:784-795

World Health Organization (2012) World Drug Report. United Nations, New York

Yang L, Rozenfeld R, Wu D, Devi LA, Zhang Z, Cederbaum A (2014) Cannabidiol protects liver from binge alcohol-induced steatosis by mechanisms including inhibition of oxidative stress and increase in autophagy. Free Radic Biol Med 68:260-267

Zawilska JB, Wojcieszak J (2014) Spice/K2 drugs-more than innocent substitutes for marijuana. Int J Neuropsychopharmacol 17:509-525

Zoethout RW, Delgado WL, Ippel AE, Dahan A, van Gerven JM (2011) Functional biomarkers for the acute effects of alcohol on the central nervous system in healthy volunteers. Br J Clin Pharmacol 71:331-350 